\title{
Economia
}





\section{A lógica da economia global e a exclusão social}

GILBERTO DUPAS

\section{Como definir a exclusão social?}

$\mathrm{P}$

OR UMA SÉRIE DE RAZÕES, começa a se generalizar - tanto em países centrais como nos menos desenvolvidos - a sensação de que a exclusão social estaria aumentando. No entanto, apesar de seu uso amplamente disseminado e de sua influência no discurso político, o termo exclusão social ainda não foi devidamente definido.

A partir da década de 80 observou-se a intensificação do processo de internacionalização das economias capitalistas, que se convencionou chamar de globalização. Algumas das características distintivas desse processo foram a enorme integração dos mercados financeiros mundiais e o crescimento singular do comércio internacional - viabilizado pelo movimento de queda generalizada de barreiras protecionistas e pela crescente presença de empresas transnacionais.

Na Europa, a discussão sobre exclusão social apareceu na esteira do crescimento dos sem-teto e da pobreza urbana, da falta de perspectiva decorrente de desemprego de longo prazo, da falta de acesso a empregos e rendas por parte de minorias étnicas e imigrantes, da natureza crescentemente precária dos empregos disponíveis e da dificuldade que os jovens passaram a ter para ingressar no mercado de trabalho.

Wolfe (1995) associa a preocupação com exclusão social à ameaça que grupos, até recentemente integrados ao padrão de desenvolvimento vigente, têm sofrido de serem marginalizados, concretizada em muitos casos, criando uma classe de novos excluidos. As recentes transformações sócio-econômicas ao gerarem uma massa de pessoas supérfluas ao sistema redirecionaram o foco das discussões sobre problemas sociais. Se antes a grande preocupação era com as condições de exploração nas quais a inserção se dava, agora ela tornou-se a dificuldade de encontrar formas de inserção social, quaisquer sejam elas. As esquerdas, de alguma forma, perderam uma de suas principais bandeiras. Se anteriormente centravam-se em críticas ao trabalho fabril nos moldes fordistas - alienante, repetitivo, não-criativo - mostram-se hoje perplexas com a nova natureza do problema; qual 
seja, encontrar formas de incorporar os indivíduos a esse trabalho. Há algum tempo, a imagem retratada por Charles Chaplin do trabalhador repetindo o gesto de apertar parafusos representava o pesadelo da Modernidade. Hoje, este posto de trabalho pode aparecer como o já distante sonho de segurança e estabilidade.

Para Rogers (1995) a abordagem de exclusão social é em sua essência multidimensional, incluindo não só a falta de acesso a bens e serviços, mas também à segurança, à justiça, à cidadania, ou seja, relaciona-se às desigualdades econômicas, políticas, culturais e étnicas. Pode-se estar excluído do mercado de trabalho (desemprego de longo prazo), do trabalho regular-part-time (1) e precário -, do acesso a moradias decentes e a serviços comunitários, do acesso a bens e serviços - inclusive públicos. A exclusão pode vir de dentro do mercado de trabalho, com empregos ruins e instáveis gerando renda insuficiente para garantir padrão de vida mínimo, como a falta de acesso à terra, à segurança e aos direitos humanos.

Silver (1995) aponta que algumas mudanças sociais e econômicas de grande envergadura geram fenômenos que passam a dominar a imaginação moral da sociedade, criando a necessidade de conceitualizá-los. O mesmo ocorre com as chamadas especificidades locais (de país para país, de diferentes regiões de um mesmo país).

Esses contextos específicos incluem o institucional (existência de políticas de welfare), o econômico (países ricos ou pobres, perfil de distribuição de renda, dinâmica de crescimento) e o entendimento de cada sociedade do que seja estar nela integrado. O conceito de exclusão social - bem como os de pobreza e desemprego - é uma resposta à necessidade de lidar com algumas características sócio-econômicas surgidas recentemente. Ela enumera, assim, mais de 20 categorias de excluídos, entre eles os sem-habilidades (skill-less), os analfabetos, os fora-da-escola, os viciados, os delinqüentes, as crianças que sofreram abuso.

É, pois, tarefa enormemente complexa tentar distinguir sentimento de exclusão, que subjetivamente é o que importa, de um critério objetivo de exclusão efetiva.

Essa complexidade é expressa com clareza na referência feita ao conceito pelo Comissariado Geral de Planejamento do governo francês: "A noção de exclusão social é saturada de significados, não-significados e contra-significados. Pode-se fazer quase qualquer coisa com o termo, já que ele exprime o ressentimento daqueles que não podem obter aquilo que reivindicam” . 


\section{Pobreza, uma dimensão fundamental da exclusão}

Nossa tendência será - de modo algum ignorando a importância das outras dimensões e percepções - optar por um recorte econômico da exclusão social. Nos países periféricos - com welfare State precário -, a incapacidade de renda própria para satisfazer às necessidades básicas deve ser o centro da definição de exclusão.

Mas o que são necessidades básicas? É a pobreza um conceito relativo? Alguns elementos que afetam a percepção social - e, portanto, a subjetividade do conceito - podem induzir a um crescimento do coeficiente de inconformismo diante da pobreza. Neles se enquadram, por exemplo, o padrão referencial de consumo da mídia de massa, projetando sobre a renda inferior ícones direcionados à classe média.

Sen (1984) chama a atenção para a limitação e a ambigüidade do critério fisiológico. Pessoas podem subsistir com uma dieta mínima, mas apresentar baixa expectativa de vida e raquitismo. Moradia, saneamento, educação e - eventualmente - bens que algumas sociedade podem considerar supérfluos (teatros, restaurantes e viagens) podem estar incluídos entre aqueles que determinada comunidade considera mínimos para uma vida socialmente aceitável.

Desai (1995) menciona o inevitável grau de arbitrariedade na demarcação entre pobres e não-pobres. Só será efetiva a definição de pobreza que a sociedade aceitar incorporar ou comprar.

Há várias implicações institucionais na definição de linha de pobreza; entre elas os critérios para ajuda (ou subsídios) do Estado. A sociedade acaba por se definir, levando também em consideração a propensão dos não-pobres em transferir renda para os pobres. Por exemplo: a sociedade está disposta a possibilitar que todas as crianças tomem leite, mas não que todos os adultos possuam uma TV. Nesse caso, o leite seria parte do conteúdo da linha de pobreza, a TV não.

A outra questão correlata é a medida geral da pobreza. O simples número de pobres na população total não leva em conta o grau em que as rendas dos pobres se distanciam da linha de pobreza, nem a distribuição de renda entre os pobres. A sugestão de Sen seria associar um income gapratio a um coeficiente de Gini (2) para a população abaixo da linha de pobreza. De qualquer forma, a renda que nos dispomos a analisar é produto de um trabalho. 
Uma profunda modificação no paradigma do trabalho está em curso na sociedade atual, com o avanço da nova lógica das cadeias produtivas do capitalismo global. Quantidade e qualidade dos empregos passam a ser uma variável decorrente da nova lógica. Para entender essa radical mudança de paradigma, é preciso analisar o processo que desencadeou a nova lógica do capitalismo global deste final de século.

\section{O capitalismo global \\ e a nova lógica das cadeias produtivas}

Foram intensos os impactos sócio-econômicos da internacionalização acelerada ocorrida nas últimas décadas. Podemos considerar que o início do processo de globalização data - no mínimo - do século XV, com a ativação do comércio marítimo mundial. A partir dos anos 80, porém, a difusão maciça da tecnologia de informação nas atividades econômicas deulhe características inusitadas e assombroso impulso.

As estratégias de produção e distribuição das corporações foram reformuladas, passando da empresa integrada verticalmente a networks, que incorporam diferentes empresas em um mesmo projeto global. Neste processo, tecnologia e capital adquiriram mobilidade crescente, acelerada pela possibilidade de fragmentação das cadeias produtivas. Assim, a mão-deobra tornou-se o único fator não-móvel, permitindo a incorporação do lowwage na lógica global.

A forte competição entre os líderes globais costuma operar como motor seletivo do capitalismo atual que, por sua vez, é alimentado pela dinâmica de duas contradições principais.

Na primeira delas, opõem-se forças de concentração e fragmentação. A concentração caracteriza-se por:

- necessidade de uma escala cada vez maior de investimentos para manter ou adquirir liderança tecnológica;

- atribuição de caraterísticas globais tanto para as networks quanto para as mídias;

- redução da quantidade de agentes que decidem o que, como, quando e onde produzir os bens e serviços.

A intensa fragmentação manifesta-se por:

- partilhamento da produção em várias plantas mundiais; 
- estabelecimento de parcerias e subcontratação com outras empresas, incluindo processos de informalização do trabalho;

- intensa utilização de elaboração de contratos e acordos de terceirização e franquias.

Como evidência da concentração, as 100 maiores corporações mundiais detêm $35 \%$ do estoque global de investimentos diretos e $80 \%$ do fluxo de pagamentos internacionais de royalties e fees (Dupas, 1996). Os líderes da produção global estão reduzidos a algumas dezenas. Até em setores como o automobilístico, tradicionalmente menos concentrado, os cinco maiores fabricantes já detêm mais de $40 \%$ da produção mundial.

A tendência do capitalismo contemporâneo é reduzir o número e aumentar o porte dos grupos por setor, operando em nível global e lutando predominantemente por mercados abertos em competição enérgica. Evidentemente há muitas tentativas de acordos e proteções, mas o processo predominante é o da concorrência.

A outra grande contradição do capitalismo contemporâneo, relacionada à geração de empregos e criação de demanda, é a coexistência de processos de exclusão e de inclusão. O capitalismo atual tem garantido a continuidade de sua dinâmica de acumulação, apesar do desemprego estrutural crescente. A queda do preço dos produtos globais incorpora porções crescentes da população ao consumo de bens ou serviços, antes restritos às frações com maior poder aquisitivo. Essa incorporação ocorre nãonecessariamente pelo incremento da renda, mas pela possibilidade de adquirir mais bens com a mesma renda.

O emprego formal apresenta uma tendência nítida de queda. Paralelamente, o trabalho flexível e a pequena e média empresa - inclusive unidades familiares informais - adquirem novo espaço de inserção por meio da tecnologia da informação, que facilita a sua integração em cadeias produtivas mais amplas.

\section{O fracionamento das cadeias produtivas}

Para Dicken (1992), da University of Manchester, a característica das corporações globais dos anos 80 é a competência de controlar sua atividade simultaneamente em vários locais e a de tirar vantagens dos diferentes fatores de produção entre países. A flexibilidade geográfica e a habilidade de deslocar seus recursos e operações em escala global são fundamentais aos modelos de gestão dos anos 90 . 
Os centros de decisão estratégica localizam-se nos países desenvolvidos, normalmente nas metrópoles globais. As atividades de pesquisa e desenvolvimento estão em clusters ou áreas de concentração de mão-de-obra qualificada. A produção é fragmentada internacionalmente, de forma a minimizar os custos totais. Os recursos mais móveis como tecnologia, management e equipamentos são levados para o local do menos móvel, a saber, a mão-deobra pouco qualificada e com condições sindicais mais frágeis.

O espaço das pequenas e médias empresas será o de integração às grandes networks, subordinando-se ao lugar por elas designado. Para Gereffi (1997), há dois tipos básicos de cadeias:

- producer-driven; as grandes manufaturas coordenando as networks, utilizando intensivamente capital e tecnologia. Como exemplos, automóveis, aviação, computadores, semicondutores e maquinaria pesada;

- buyer-driven; fundamentalmente os grandes varejistas, designers e trading networks - descentralizados em vários exportadores - especialmente no Terceiro Mundo. É o caso dos calçados, brinquedos, roupas e dos bens de consumo eletrônicos. Eles não fabricam, somente controlam como, quando e onde a produção irá acontecer e que parcela de lucro deve ser auferida a cada estágio da cadeia. Dessa forma, externalizam seus riscos: é bem mais fácil romper um contrato de subcontratação do que fechar uma planta acarretando desgastes de imagem e problemas legais.

\section{O atual padrão \\ de investimento direto internacional}

As empresas transnacionais constróem a parte própria de suas cadeias globais de produção fundamentalmente com investimentos diretos, seja por aquisição de capacidade instalada, seja por construção de novas fábricas ou ampliação das mesmas.

Há um elo crescente entre o comércio internacional e o investimento direto, que resulta coerente com a lógica das cadeias globais. Em 1993, por exemplo, a troca de componentes, produtos finais e serviços entre as transnacionais já era responsável por $44 \%$ das exportações norte-americanas (Unctad, 1994).

As políticas de construção de blocos regionais (Dupas, 1997) também têm efeitos significativos nas decisões estratégicas das transnacionais e 
na formação das suas cadeias globais ao favorecer políticas de investimento direto nos países da mesma região, seja por incentivos tributários, seja pela simples ampliação da escala de produção.

A atual reestruturação da correlação de forças entre capital, trabalho e Estado provoca e aprofunda a crise do Estado Nacional contemporâneo. Os fatores fundamentais envolvidos referem-se ao enfraquecimento da sua estrutura orçamentária, a despolitização ocasionada pelo fim da Guerra Fria - com os grandes problemas de alinhamento ideológico acarretados e à freqüente incompetência dos serviços e empresas públicas.

Por essas e outras razões que serão analisadas posteriormente, estamos assistindo a um profundo questionamento do modelo de Estado que conduziu à evolução do capitalismo nos anos do Pós-guerra. Reconfigurada a situação política e econômica que lhe dera origem, a sua base de sustentação está fragilizada.

A radicalização da utilização da tecnologia da informação e da reestruturação produtiva, aprofundadas nos anos 90 , outorgam vantagens estruturais ao capital representado pelas grandes corporações. A possibilidade crescente de fragmentação e relocalização da produção, aliada à flexibilidade das formas de gestão e à relativa fragmentação internacional de sua lógica de controle, conduz a uma progressiva perda de identificação das transnacionais com seus países de origem, apesar da manutenção de suas sedes nacionais.

\section{As cadeias produtivas e a geração de empregos}

A lógica das novas cadeias produtivas atinge diretamente a geração e a qualidade dos empregos na economia contemporânea, bem como sua distribuição regional pelos diferentes países do mundo.

Modificações ocorridas no seio das cadeias produtivas globais alteram de modo decisivo a forma como os países e os agentes econômicos relacionam-se entre si, apropriam-se da riqueza, alteram o mapa da produção mundial, a demanda por trabalho e a força relativa dos diversos grupos de trabalhadores. A ampla fragmentação do processo produtivo, a progressiva fragilização das fronteiras nacionais e a flexibilização dos transportes geraram uma alteração nos padrões de produção, nos sistemas de gestão e na forma de utilização da mão-de-obra.

Paralelamente à forte concentração no topo das cadeias - com as transnacionais líderes e seus global supliers concentrando-se cada vez mais 
por fusões, aquisições, joint-pentures e acordos tecnológicos - presencia-se uma forte fragmentação na sua base, por processos de franquias, terceirização, subcontratos e parcerias como forma de otimizar vantagens e custos de fatores de produção (figura 1).

Graças à nova articulação produtiva, as transnacionais podem se apropriar das vantagens das reservas de low-wage labor, das relações contratuais informais e das regras ambientais menos rigorosas, sem um envolvimento necessariamente direto de sua marca institucional.

Evidências de flexibilização do trabalho são encontradas também no topo das cadeias, mediante a ruptura de contratos formais de trabalho com altos executivos e quadros gerenciais, com sua recontratação como consultores.

Enquanto a nova lógica das cadeias, seleciona, reduz e qualifica em direção ao seu topo (e, portanto, exclui), também tende a incluir - em direção a sua base - trabalhadores com salários baixos e contratos flexíveis, quando não informais.

Esses processos condicionam cada vez mais os mercados de trabalho mundiais, já que, nos países desenvolvidos e em certos países em desenvolvimento, as transnacionais chegam a gerar cerca de $20 \%$ do emprego formal não-agrícola.

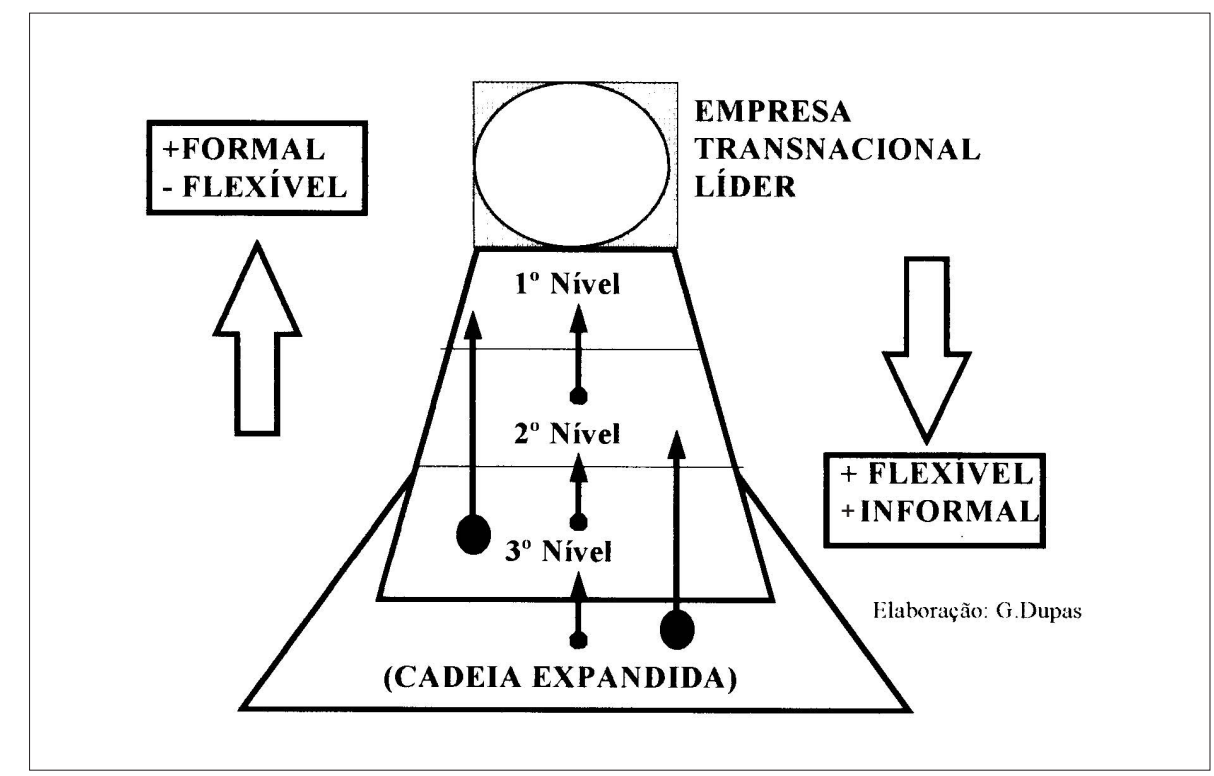

Figura 1: Lógica das cadeias produtivas globais e empregos

(filiais, subcontratados e parceiros) 
Os fortes vínculos com empresas subcontratadas, fornecedores e outros agentes econômicos nos países de origem e nos hospedeiros geram (Unctad, 1994) um multiplicador de um a dois empregos diretos e indiretos na base, para cada emprego no topo. Significa dizer que, em certos países, as cadeias globais já chegam a gerar e a induzir quase $40 \%$ da mão-deobra empregada no setor não-agrícola.

$\mathrm{Na}$ última década, no entanto, o número de pessoas diretamente empregadas por transnacionais cresceu mais devagar do que o valores nominais de seus investimentos diretos. Ou seja, para cada dólar adicional de investimento direto, um número decrescente de empregos formais diretos está sendo gerado. Já era assim entre 1975 e 1985, mas a tendência agravou-se no período que se seguiu, sendo suas causas fundamentais:

- aceleração da integração das cadeias;

- aplicação de tecnologias modernas poupadoras de trabalho;

- técnicas de lean production;

- acordos de out sourcing intrafirmas e de subcontratação, com queda do emprego direto e crescimento do indireto;

- fusões e aquisições, que levam ao rearranjo dos empregos existentes com cortes de excedentes.

Apesar de sempre existir um custo de saída, as transnacionais têm relativa facilidade de transferir o local de sua produção. A decisão de investir no país de origem ou no exterior tem implicações importantes sobre os níveis de emprego dessas economias e, muitas vezes, é utilizada como ferramenta de negociação pelas empresas. A mobilidade do capital e a possibilidade de deslocar segmentos da cadeia produtiva para outro país desestabilizam a estrutura de salários ao referenciá-la por padrões internacionais.

Recente pesquisa efetuada pela OIT (1997/98) em 600 empresas dos EUA revelou que em 50\% dos casos os empregadores utilizaram o argumento ou a ameaça de transferência da produção como forma de oposição aos sindicatos e em 10\% deles, parte da produção foi efetivamente transferida.

Nos países desenvolvidos uma série de fatores tem afetado a evolução do emprego. Entre os principais, fusões e aquisições; rearranjo dos empregos existentes com cortes de excedentes; deslocamento setorial do investimento direto para serviços - comércio, finanças e construção civil - com uso intensivo de tecnologias poupadoras de trabalho. Apesar do aumento 
do volume de investimento direto nesses países - os seus principais receptores - o crescimento de empregos foi muito modesto.

Glickman \& Woodword (1989) afirmam que o efeito dos investimentos das transnacionais norte-americanas no exterior sobre os empregos domésticos líquidos de 1977 a 1986 significou a perda líquida de 2,7 milhões deles; 3,3 milhões de postos de trabalho foram deslocados por investimentos externos e 600 mil criados nas matrizes para fortalecer sua central de gestão. O desemprego é maior entre mulheres, minorias e blue collar workers. Mas, teriam essas empresas sobrevivido se não se internacionalizassem?

Outro fantasma que paira sobre os países desenvolvidos é a chamada desindustrialização, ou seja, o declínio dos produtos manufaturados em direção aos serviços, a queda relativa do produto e do emprego industriais e a inabilidade de competir nos processos manufatureiros internacionais.

Há conexões entre o deslocamento das cadeias globais e a dificuldade dos países desenvolvidos na manutenção do emprego industrial. As reestruturações e racionalizações dos últimos anos aprofundaram o problema do desemprego e a implementação de novas tecnologias poupadoras de trabalho prejudicou fundamentalmente os empregos dos trabalhadores menos qualificados nesses países.

A tentativa de tornar variáveis todos os custos fixos, que acabou por envolver uma radicalização na flexibilização da mão-de-obra, é outra razão apontada e o avanço do trabalho em tempo parcial é parte deste processo.

As novas tecnologias também geram novas oportunidades de emprego, mas as qualificações dos trabalhadores disponíveis normalmente não se adequam ao seu perfil, agravando - ainda que temporariamente - a questão do desemprego.

\section{O difícil dilema dos países em desenvolvimento}

Os problemas enfrentados pelos países centrais são insignificantes se comparados aos efeitos da nova lógica das cadeias produtivas nos países em desenvolvimento. Nestes, a renda está diretamente associada ao trabalho, já que quase inexistem políticas de welfare. Assim, como lembra o Banco Mundial (1997) em seu último Relatório “o pobre não pode se permitir estar desempregado; ele é obrigado a aceitar o subemprego".

O emprego direto em empresas transnacionais cresceu rapidamente em vários dos países mais pobres, especialmente mediante mecanismos de 
Zonas de Processamento de Exportações (ZPEs). Na década de 90, já estamos assistindo à segunda geração de ZPEs. O custo médio do trabalho com relação aos países de primeira geração subiu, o que é positivo. Bom exemplo a ser citado é a China, com joint-pentures e green-field investments orien-tados ao trabalho intensivo. O país tem recebido cerca de US\$ 40 bilhões de investimentos diretos anuais nos últimos anos com as instalações de transnacionais em território chinês, exportando praticamente o equivalente desse valor anualmente. O governo comunista subsidia - na prática essas corporações globais, já que complementa os baixos salários com políticas públicas de moradia, vestuário e alimentação.

Na maioria das ZPEs o trabalho apresenta baixa ou nenhuma qualificação além de relações sindicais frágeis. As mulheres jovens constituem $70 \%$ dos empregados, submetendo-se em muitos casos a longas jornadas, trabalho noturno, alta rotatividade, e pouca estabilidade. Apesar disso, os salários e a qualidade do trabalho das ZPEs tendem a ser melhores do que os proporcionados pelas fontes locais ainda que, em alguns casos, mesmo a quantidade dos empregos indiretos gerados possa ser expressiva, a qualificação e a remuneração são muito baixas.

A reformulação das estratégias das transnacionais influencia diretamente a autonomia dos mercados de trabalho e as regulamentações e os sistemas de welfare. Mercados de trabalho geograficamente dispersos acabam competindo pelos mesmos empregos, pressionando e ajustando em patamares inferiores os padrões sociais e de relações de trabalho, à medida em que são fatores decisivos para tornarem competitivas as economias nacionais.

A nova lógica das cadeias globais afeta, pois, a qualidade e a quantidade da oferta global de empregos de maneira complexa. As principais tendências que se evidenciam são:

- redução da geração de empregos qualificados e formais por investimento direto adicional;

- contínua flexibilização da mão-de-obra em todos os níveis, no sentido de transformá-la em componente radicalmente variável do custo final dos produtos globais;

- clara inter-relação entre agentes econômicos formais e informais, na medida que se caminha para a base das cadeias produtivas, procurando abrigar o trabalho informal e low wage.

Ainda não há condição de afirmar - com segurança - que o capitalismo 
global em sua forma atual reduzirá substancialmente a oferta agregada de empregos (formais e informais, diretos e indiretos) no mundo. Tal perspectiva, porém, parece provável.

Em países como o Brasil, o processo de internacionalização da economia local - com contínuas aquisições de empresas nacionais por transnacionais e com a velocidade das privatizações - torna muita rápida a incorporação de padrões de produtividade global, afetando fortemente a lógica dos empregos locais.

A discussão entre Robert Reich, então secretário do trabalho de Clinton, e Robert Eaton, presidente do Conselho da Chrysler, elucida os termos da questão: Reich acusava as transnacionais de não terem responsabilidade social enquanto Eaton afirmava que o papel das corporações era crescer, remunerando adequadamente seus acionistas e gerando os empregos possíveis; o que revela um panorama dos empregos no mundo atual radicalmente diferente da fantasia liberal de Peter Drucker (1982), quando chegou a imaginar que as transnacionais dominariam o mercado mundial de trabalho, nivelando-o por cima e encarregando-se da proteção dos cidadãos, levando-nos a refletir sobre papel dos Estados nacionais e das instituições internacionais na economia global atual.

\section{A nova lógica global e o papel dos Estados}

A década de 90 iniciou-se sobre as ruínas do muro de Berlim, entronizando o mercado como instância suprema de coordenação das atividades econômicas e instigando os Estados a baterem em retirada (Dupas, 1998).

O vácuo teórico e a incapacidade de gestão dos Estados nacionais, fenômenos que se seguiram à crise dos anos 70, abriram espaço para os ardorosos defensores do Estado minimo. A idéia de que o Estado tende intrinsecamente à ineficiência voltou com toda força quando se evidenciaram os problemas de financiamento e gestão dos governos nos países desenvolvidos.

As políticas de revisão do Estado praticadas nas últimas duas décadas tornaram eficaz o longo ciclo de privatizações - ainda em curso - que possivelmente aprimorará a infra-estrutura de vários países, devendo supostamente viabilizar a queda do seu custo. Além disso, a saída progressiva dos Estados nacionais como produtores de bens e serviços poderá aliviar os caixas de seus Tesouros, dilapidados pelos déficits recorrentes de suas empresas estatais ineficientes. 
No entanto, os processo de globalização das economias e de privatização da infra-estrutura pública, apesar de trazerem vários benefícios à eficiência econômica, têm gerado uma tendência mundial de aumento do desemprego formal e crescente flexibilização da mão-de-obra. Como conseqüência, os governos acabam inevitavelmente pressionados a garantir certa proteção social às crescentes populações carentes, sem coerência com seus recursos orçamentários fragilizados pela meta imperiosa de contenção dos déficits. $\mathrm{O}$ não-atendimento a essas expectativas tem gerado progressivo aumento da dissonância entre populações e governos, com impactos futuros não-desprezíveis.

O próprio Banco Mundial parece estar assumindo posições flexíveis a respeito do papel do Estado. Segundo seu Relatório de 1997: "Com a crescente competição e insegurança no trabalho, os trabalhadores irão depender mais de recursos estáveis para seguro-desemprego, educação e treinamento nos próximos anos. Na ausência desses programas governamentais, o suporte político para a globalização seria erodido." Assim, o Relatório do Banco Mundial parece confirmar essa tendência. Na figura 2 demonstra-se uma relação positiva entre o nível de abertura econômica e os welfare transfers.

Na realidade, ocorre claramente o que se poderia chamar efeito democracia: aumenta o número de desempregados e pobres, crescendo sua base política. Introduz-se, assim, certa contradição entre o discurso liberalizante das elites e sua práxis política. Cresce a voz dos que clamam por maiores garantias sociais por parte do Estado. Ainda conforme o Relatório do Banco Mundial: "A integração global das economias e a difusão da democracia reduziu o espaço para políticas arbitrárias. Impostos, regras de investimento e políticas econômicas têm que responder às normas da economia globalizada. O desenvolvimento econômico e social sustentável mostra-se, pois, impossível sem um Estado ativo. Um Estado atuante - e não um Estado mínimo - é central ao desenvolvimento econômico e social, ainda que como parceiro e facilitador."

O último Relatório da OIT (1997/98) também lembra: “Economistas tendem a pensar no mercado e no governo como substitutos. Contrariamente, porém, ao que muitos deles poderiam esperar, o escopo da ação do governo tem crescido, e não diminuído. Com efeito, reduzir as dimensões do Estado - o que tem sido uma tendência dos anos 90 - pode ameaçar a manutenção do livre comércio em escala global. A globalização requer grandes, e não pequenos governos.” 


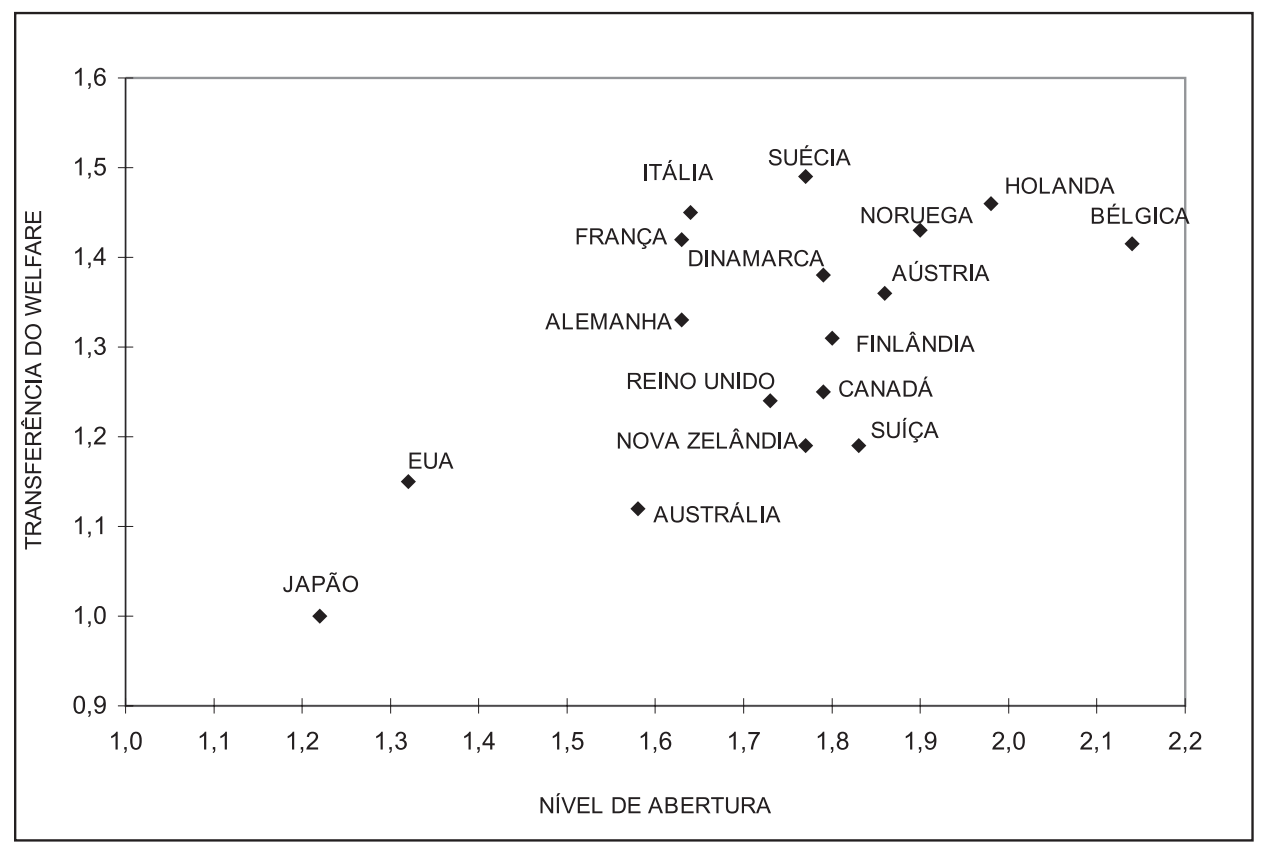

Figura 2: Abertura e transferência do welfare em 1993 (\% do PIB)

Fonte: Word Labour Report - Industrial relations, democracy and social stability - 1997/98.

De fato, as despesas de proteção social dos governos têm aumentado rapidamente como porcentagem do produto nacional bruto. Dados do The Economist (20/9/97) e de Jean-Pierre Dumont (1995) - apresentados na tabela 1 - comprovam tal afirmativa, apesar de sua velocidade de crescimento ter diminuído nos anos 90. É provável que parte importante desse incremento de gastos tenha sido direcionada para completar déficits dos sistemas de previdência ou para alicerçar programas de seguro-desemprego.

Os números do The Economist mostram que mesmo nos EUA, embora com percentuais menores que em outros países, também foram mantidas taxas crescentes de gastos governamentais, especialmente transferências e subsídios.

Para melhor entender a questão do papel dos Estados deve-se considerar os anos 60, quando o keynesianismo ainda era a ideologia oficial do compromisso de classe, sob a qual diferentes grupos pareciam poder entrar em conflito nos limites de um sistema capitalista e democrático. O Estado provedor de serviços sociais e regulador de mercado tornava-se mediador das relações - e dos conflitos - sociais. 
Tabela 1: Despesas de proteção social (em percentagem do PIB)

\begin{tabular}{lcccc}
\hline País & 1970 & 1983 & 1989 & 1992 \\
\hline Países Baixos & 19,60 & 33,47 & 31,00 & 33,00 \\
Dinamarca & 19,60 & 30,10 & 29,90 & 31,40 \\
França & 18,90 & 28,30 & 27,50 & 29,20 \\
Luxemburgo & 15,60 & 27,20 & 25,20 & 28.00 \\
Bélgica & 18,70 & 30,80 & 26,70 & 27,80 \\
Alemanha & 21,50 & 28,80 & 27,50 & 27,30 \\
Reino Unido & 14,30 & 23,90 & 21,70 & 27,20 \\
Itália & 14,40 & 22.90 & 23,10 & 25,60 \\
Espanha & 10,00 & 19,50 & 20,00 & 22,50 \\
Irlanda & $13,70-$ & 24,10 & 19,70 & 21,60 \\
Grécia & 7.60 & 17,40 & 20,80 & 19,30 \\
Portugal & 9,10 & 14,10 & 14,50 & 17,60 \\
\hline
\end{tabular}

Fonte: Les systèmes de protection sociale en Europe, Jean-Pierre Dumont, 1995.

A crise do keynesianismo foi, na verdade, a das políticas de administração de demanda e tornou-se mais nítida a partir dos anos iniciais da década de 70 quando se desenhou um quadro de inflação com baixas taxas de crescimento econômico. O mercado acabou, então, promovido para instância reguladora por excelência das relações econômicas e sociais no capitalismo contemporâneo. Ao mercado caberia determinar, inclusive, o tipo e a quantidade de investimento na economia, decisão privada com profundos impactos públicos.

“O Estado é um elefante. Ao contrário das andorinhas, o elefante simplesmente não pode voar”, já dizia Drucker (1982) atribuindo às empresas transnacionais a condição de serem também os novos agentes sociais da era globalizada: caberia a elas providenciar, desta vez de forma eficiente, os benefícios sociais ao seu amplo quadro de colaboradores - em todas as partes do mundo - que os Estados nacionais não conseguiam prover. Essa hipótese tornou-se rapidamente fantasiosa. Em artigo escrito 15 anos depois em Foreign Affairs (12/9/97), muito mais realista, ele já reconhece 
que o Estado nacional, apesar do fenômeno da globalização da economia mundial, vem revelando surpreendente resistência. Drucker o chama de "um sobrevivente de fibra". No entanto, acredita que a nova economia mundial globalizada estaria impondo aos Estados novas e mais rigorosas exigências. Caberia a eles, agora, a execução de políticas fiscais e monetárias que evitassem a dependência dos países do volátil fluxo financeiro internacional de curto prazo, destinado a cobrir seus déficits.

Outro grande problema refere-se ao crescimento da percepção das sociedades de que o novo modelo global de produção agrava a exclusão social. Tal fato tende a aumentar a sensibilidade dos Estados nacionais, promovendo a retomada de políticas públicas eficazes na área social e reintroduzindo a dúvida sobre a quem cabe gerar empregos na economia globalizada. As grandes corporações mundiais, fugaz esperança do início da década de 80, têm mantido a esse respeito clara posição: seu papel limita-se a melhorar a competitividade para crescer, remunerar seus acionistas e, em decorrência, manter os empregos possíveis, usando, quando for o caso, o lowwage dentro da lógica de suas cadeias produtivas, como já mencionado.

De qualquer forma, dado que os orçamentos nacionais dos países em desenvolvimento estarão mergulhados na imperiosa tarefa de eliminar déficits e garantir estabilidade, o caminho mais viável para avançar em programas sociais será aumentar dramaticamente sua eficácia, o que deverá envolver estruturas ágeis e amplo comprometimento da sociedade civil e dos movimentos sociais na gestão de projetos .

Será necessário, igualmente, fortalecer a capacidade de indução dos Estados nacionais - aprimorando-os em sua ética e legitimidade de tal forma que tenham condição de formular políticas públicas viáveis voltadas ao amparo à exclusão, estimular a sociedade a apoiá-las e financiá-las e fiscalizar o cumprimento dos acordos e dos compromissos assumidos. Esses são os imensos desafios a serem ainda enfrentados, não mais para reduzir radicalmente o papel do Estado, mas para modificá-lo profundamente, transformando-o e fortalecendo-o para exercer novos papéis fundamentais.

\section{A evolução dos mercados de trabalho e do desemprego}

Há, obviamente, uma forte correlação entre emprego e crescimento econômico. Vários países desenvolvidos por nós pesquisados revelaram um r2 (2) entre $0.90 \%$ e $0.98 \%$ nas décadas de 80 e 90 . É o caso de Alemanha, França, Reino Unido, Itália e Japão, confirmando o senso comum que o único caminho garantido para o aumento dos empregos ainda é o crescimento econômico. 
Para além do ciclo econômico, porém, há evidências de uma tendência estrutural para o aumento do desemprego a partir dos anos 80 , período que corresponde justamente ao acirramento do processo de globalização observado para alguns países, conforme demonstrado no gráfico 1. As únicas exceções são EUA e Reino Unido. No primeiro caso, há pelo menos duas boas razões para esse desempenho. Sua condição de economia hegemônica e líder do processo de inovação tecnológica parece lhe ter dado melhores condições de atenuar os impactos negativos no mercado de trabalho por uma significativa expansão das ofertas de empregos no setor de serviços, especialmente os não-tradicionais, o que pode ser observado no quadro 1. Ao mesmo tempo, a flexibilização do seu mercado de trabalho e a fragilização do seu esquema sindical permitiram a redução das remunerações médias - ao contrário da grande maioria dos países europeus, onde os sindicatos lutaram pela manutenção dos salários e benefícios, impactando negativamente a geração de empregos.

Há de se levar em conta, também, que esse período coincidiu com uma forte incorporação da mulher ao mercado de trabalho, fazendo crescer mais rapidamente a população economicamente ativa e pressionando as taxas de desemprego.

No Brasil, a mesma correlação entre crescimento do PIB e dos empregos é encontrada, mas com r2 significativamente mais baixo que o dos países centrais. Como conseqüência da forte instabilidade econômica e das mudanças acentuadas de paradigma na economia brasileira a partir dos anos 80 , em vários momentos os ajustes de emprego se deram de forma diversa (gráfico 2).

O final dos anos 70 caracterizou-se pela última etapa do processo de substituição de importações. O II Plano Nacional de Desenvolvimento (PND) optava pela estratégia do endividamento externo acelerado. A enorme elevação da dívida interna decorrente da emissão de títulos públicos equivalentes, a sua pressão sobre a base monetária e os altos juros alimentaram a inflação.

A partir de 1980 o já enfraquecido regime militar teve que optar por um ajuste via recessão e obtenção de superávits comerciais. A dificuldade de crédito externo e a crise mexicana em 1982 forçaram a primeira onda de ajustes estruturais (Pomeranz \& Nunes Ferreira, 1996) na economia brasileira e apressaram o fim do regime (Dupas, 1986). Foi um momento de forte recessão, com o PIB caindo 3\%, quando o desemprego bateu - então o recorde do período ( $8 \%$ pelo IBGE), voltando a ser igualado apenas no segundo semestre de 1998. 


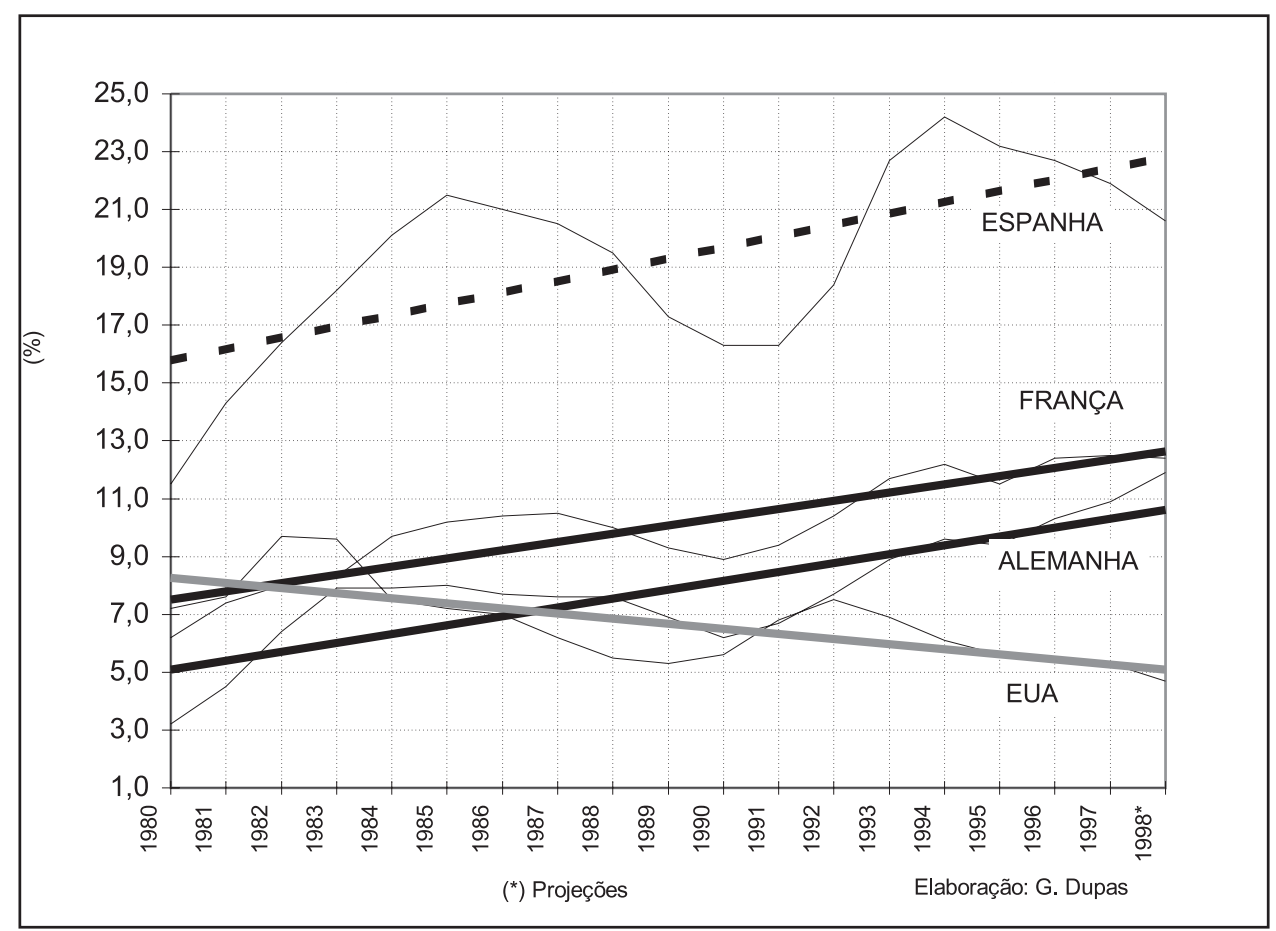

Gráfico 1: Tendências de taxas de desemprego internacionais (1980-98)

Fonte: OECD Economic Outlook.

Quadro 1

Setores que mais geraram aumento (redução) de empregos

(EUA, jan. 1990/jun. 1995)

\begin{tabular}{|ll|lr|}
\hline \multicolumn{2}{|c|}{ Os que mais empregaram } & \multicolumn{2}{c|}{ Os que mais demitiram } \\
\hline Agências de serviços temporários & 899.000 & Aviação & -251.000 \\
Enfermagem, cuidados & & Bancos \\
e saúde pessoal & 786.000 & e Instituições de poupança & -247.000 \\
Restaurantes e bares & 738.000 & Roupas femininas e lojas & -141.000 \\
Governos locais e estaduais & 587.000 & Equip. de busca e navegação & -128.000 \\
Hospitais privados & 345.000 & Computação (hardware) & -116.000 \\
Recreação & 344.999 & Mísseis e veículos espaciais & -90.000 \\
Consultórios médicos & 290.000 & Construção residencial & -60.000 \\
Computação (software) & 255.000 & Estradas de ferro & -51.000 \\
Serviços de entrega & 222.000 & Atacadistas de máquinas & -48.000 \\
Serviços de apoio a negócios & 204.000 & Componentes eletrônicos & -47.000 \\
\hline
\end{tabular}

Fonte: Fortune/Nuala Beck \& Associates. 


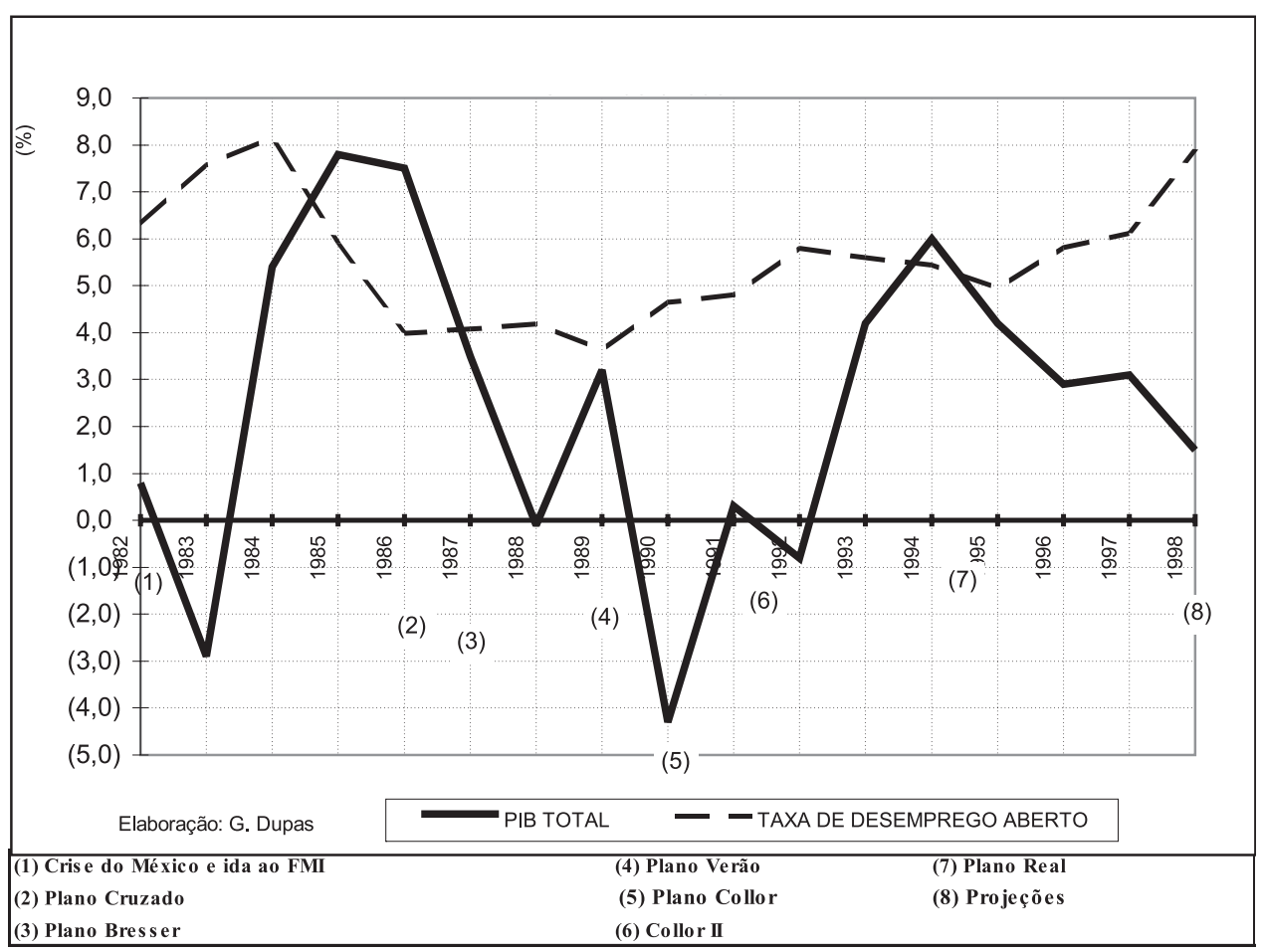

Grafico 2: Taxas de crescimento do PIB e do desemprego metropolitano, Brasil - 1982/1998

Fonte: IBGE.

Após esse período de forte contração, o desempenho exportador levou à relativa recuperação do PIB. O desemprego caiu drasticamente para o patamar de 4\%, no qual permaneceu até 1990, apesar de ter ocorrido nova dramática queda do PIB, o que foi possível porque a variável de ajuste foi a queda no rendimento real dos salários. Nessa época a indústria local ainda se modernizava defensivamente, e os cortes de mão-de-obra eram cautelosos por haver expectativa de uma rápida recuperação. São desse período várias tentativas de estabilização: os Planos Cruzado, Bresser e Verão.

A segunda onda de ajustes estruturais (Pomeranz \& Nunes Ferreira, 1996) aconteceu a partir de 1990, com o Plano Collor (Dupas, 1993). A radical abertura comercial, concomitante às taxas negativas do PIB, forçou o nível de desemprego a novo patamar (6\%). A necessidade imperiosa de competir obrigou o setor produtivo a uma profunda e contínua reestruturação preventiva, com automação radical e terceirizações, além de redução de níveis hierárquicos e estruturas administrativas e técnicas da lean production. Procedimentos orientados para maior flexibilidade, de acordo com o novo paradigma. Durante curto período houve recuperação da taxa 
do PIB, mas a partir de 1994 entrou em declínio novamente. No gráfico 2 pode ser observado como a sensibilidade do desemprego à queda do PIB parece se acentuar mais recentemente, principalmente após a crise da Ásia no final de 1997. De qualquer forma, os anos 90 não significam uma recuperação. O país, que já havia vivido a década perdida, volta a apresentar uma evolução acumulada de modestos 5\% per capita (1990 a 1997) - significando uma média anual de apenas $0,6 \%$ a.a - com inevitáveis conseqüências sobre o emprego.

Grandes alterações ocorreram com relação à dinâmica da população brasileira nesse período, principalmente uma imensa urbanização. Nos últimos 50 anos, em virtude da mudança do padrão tecnológico no campo e da dinâmica demográfica, a população das cidades brasileiras passou de $12 \mathrm{mi}$ lhões para 130 milhões de pessoas em um dos maiores processos de deslocamento populacional da história mundial. Essa migração originou principalmente os cinturões de pobreza urbanos, em especial os metropolitanos, constituindo imenso estoque de reserva de mão-de-obra não-qualificada e mal acomodada no subemprego. A face da pobreza no Brasil passou a ser predominantemente metropolitana.

No gráfico 3 é demonstrado, conforme dados dos Censos 1980/1991/ 1996, o contínuo esvaziamento do campo e a explosão das cidades pequenas e médias. Com triste ironia, é o que se poderia chamar de "saturação dos faróis de trânsito e dos baixos de viadutos". Os dados anuais da PNAD, plotados em pontilhado, no gráfico, poderiam levar a conclusões parciais um pouco diferentes, mas menos confiáveis em função de limitações amostrais.

Vamos, agora, analisar as conseqüências desses processos sobre o desemprego no Brasil. Em função da carência de dados estatísticos confiáveis e compatibilizáveis, infelizmente teremos que concentrar nossas análises sobre o desemprego no Brasil metropolitano, e a partir do início dos anos 80 quando as séries são mais consistentes, o que introduz limitações importantes, embora não insuperáveis, em nossas conclusões.

No gráfico 4 é demonstrada a dinâmica dos empregos nas metrópoles a partir de 1985. Pode ser verificada tendência geral de crescimento do desemprego em dois períodos distintos: até 1990, nos setores indústria, serviços e construção civil houve aumento de $20 \%$ no número de empregos, destacando-se o da construção civil (28\%); a partir de 1990, os empregos no setor industrial desabam (-34\%), na construção civil diminuem $8 \%$ e só no setor de serviços crescem um pouco. Em seis anos (1991-1997) o Brasil metropolitano perdeu $4 \%$ dos seus empregos, quando havia ganho $20 \%$ nos cinco anos anteriores. 


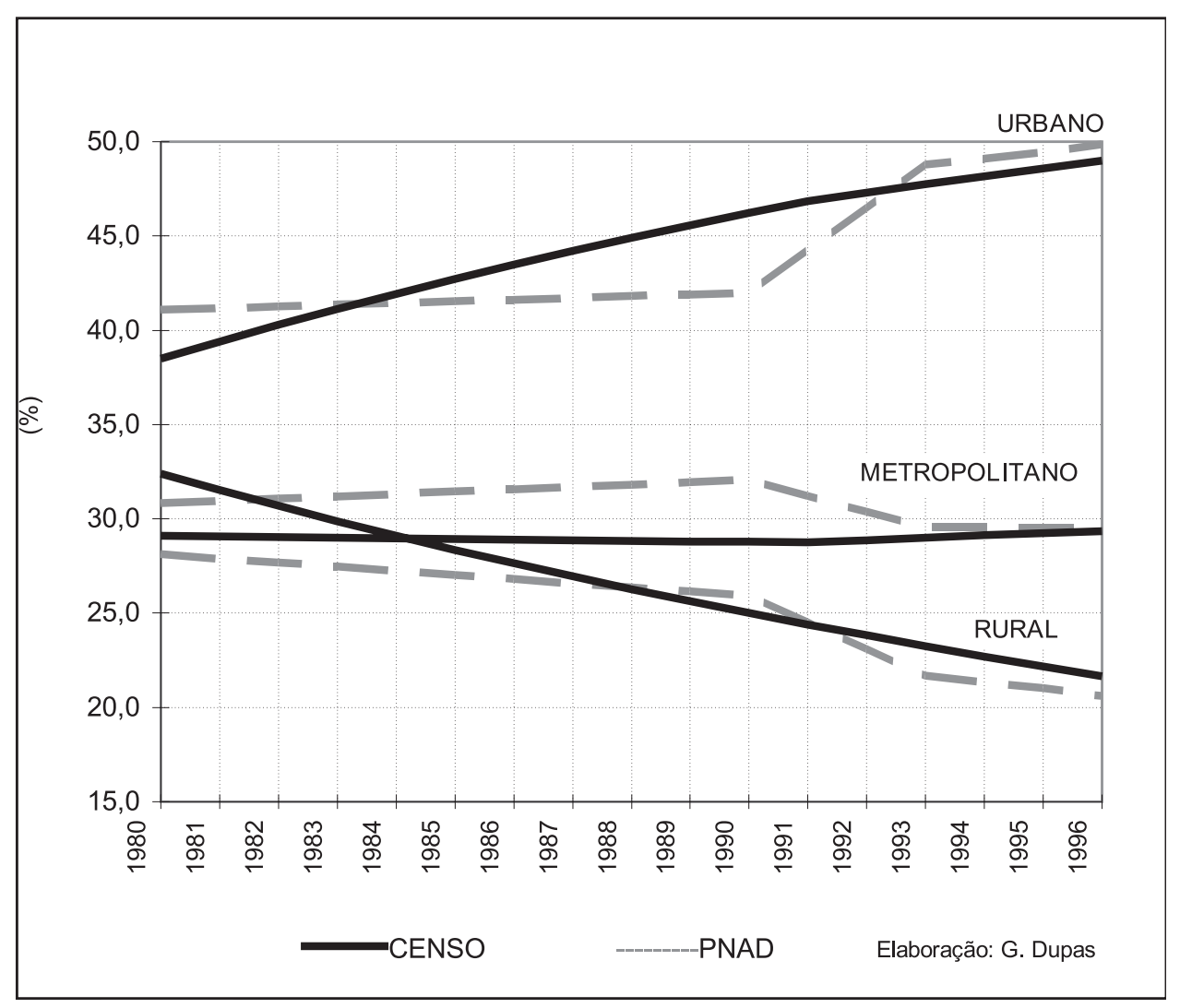

Gráfico 3: Distribuição da população segundo os estratos, Brasil 1981-1996 Fonte: IBGE.

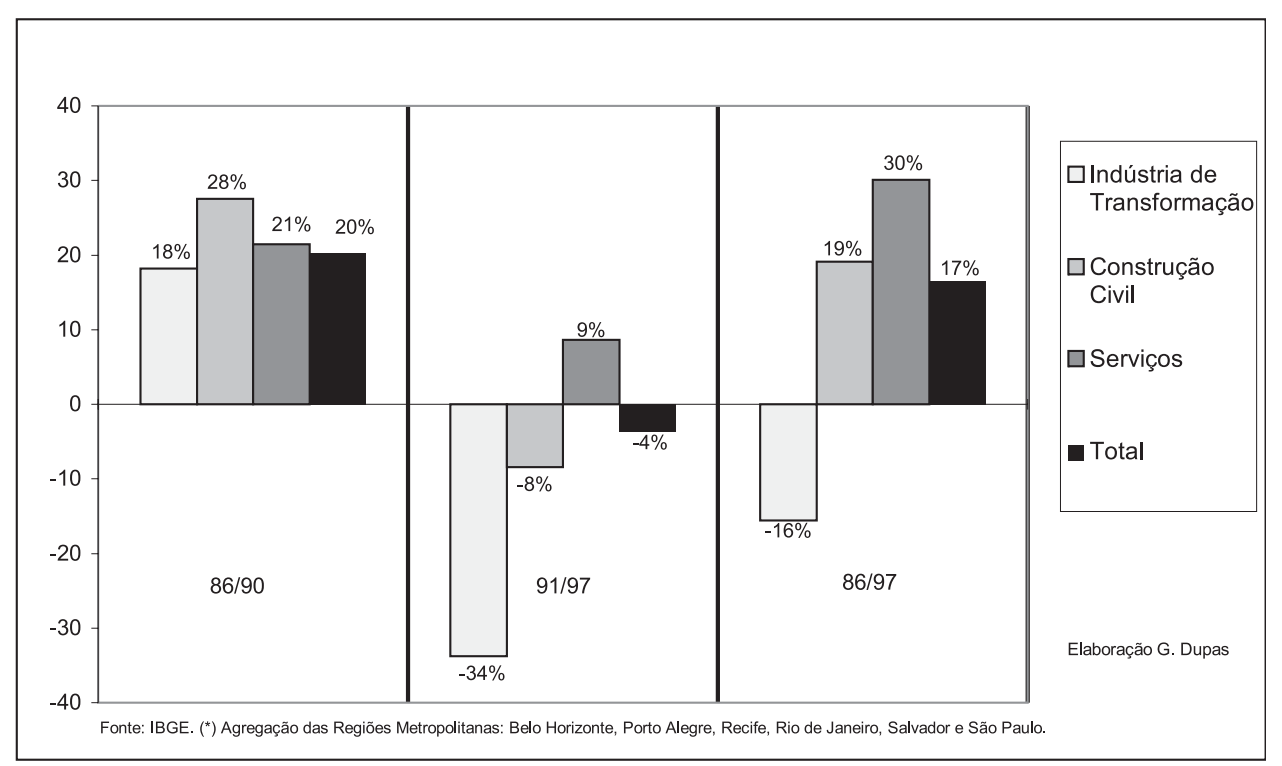

Gráfico 4: Porcentagem de empregos gerados (perdidos) por setor de atividade Brasil metropolitano* ${ }^{*}$ 1986-1997 
No total do período a grande alteração foi a dramática queda dos empregos industriais e o forte crescimento do emprego em serviços, setor no qual o informal é mais típico. Essas conclusões precisam ser relativizadas pelo recente deslocamento de atividades industriais das regiões metropolitanas para cidades menores, visando às condições sindicais e salariais mais favoráveis ao empregador. Ainda assim, a tendência geral e as conclusões básicas se mantêm.

Como resultado a evolução da distribuição das pessoas empregadas nas metrópoles sofreu importante transformação com o aumento no setor de serviços e a queda no industrial, o que pode ser visualizado no gráfico 5 .

Um corte fundamental para o entendimento da mudança de paradigma do emprego no Brasil é a analise da evolução do tipo de ocupação, evidenciada pela explosão do trabalho informal nas metrópoles brasileiras.

A observação do gráfico 6 mostra ter ocorrido um comportamento muito diferente após 1990 - ano que mais se caracterizou como um momento de ruptura com o antigo paradigma do mercado de trabalho local. O número de empregos gerados com carteira assinada desaba de um crescimento de 23\% (1986-1990) para 28\% negativos (1991-1997); paralelamente, os trabalhadores sem carteira, de um modesto crescimento de 5\% (1986-1990) vão para 27\% (1991-1997). Este movimento significou, nos últimos seis anos, uma perda de 2,2 milhões de postos de trabalho no setor formal e um ganho de 1,7 milhões no informal (quadro 2), o chamado "informal por conta própria" obteve nível recorde de crescimento nos dois períodos, sempre em aceleração. No total, durante o período analisado, os trabalhadores com carteira perderam $5 \%$ dos postos, os sem carteira ganharam $32 \%$ e os por conta própria saltaram $70 \%$ acima de seu nível em 1985.

O grande avanço da categoria "conta própria”, que foi o principal gerador de postos de trabalho desde 1986 - 1,7 milhões de ocupações deve ter absorvido boa parte dos trabalhadores com carteira que mudaram de ocupação e precisa ser investigado com critério. Nessa categoria são incluídos, entre outros, cabeleireiros, taxistas, ambulantes e também, consultores e profissionais liberais. Conseqüentemente, a disparidade de renda tende a ser muito grande, convivendo acentuada precariedade com razoável estabilidade. Já os trabalhadores sem carteira parecem ter perfil mais homogêneo, sua categoria incluindo empregados domésticos e trabalhadores da pequena indústria e do setor de serviços. 


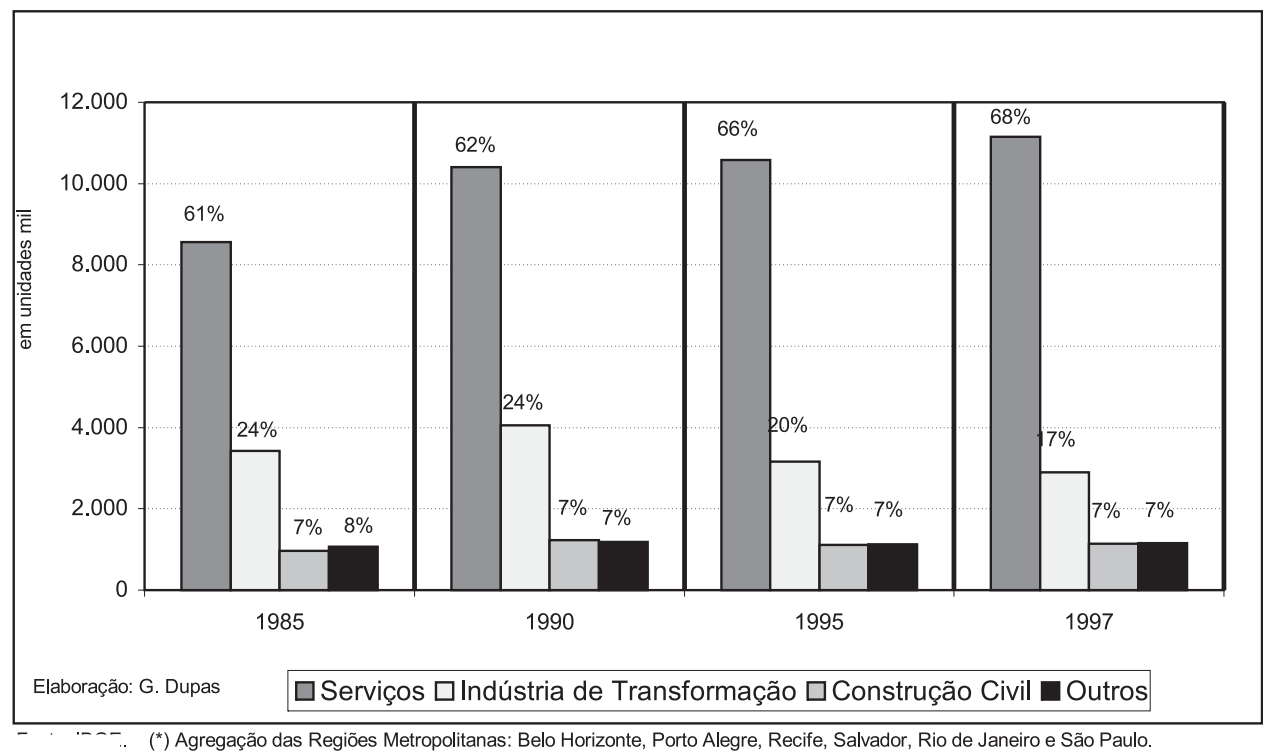

Gráfico 5: Número absoluto e distribuição relativa dos ocupados por setor de atividade - Brasil Metropolitano*

Fonte: IBGE.

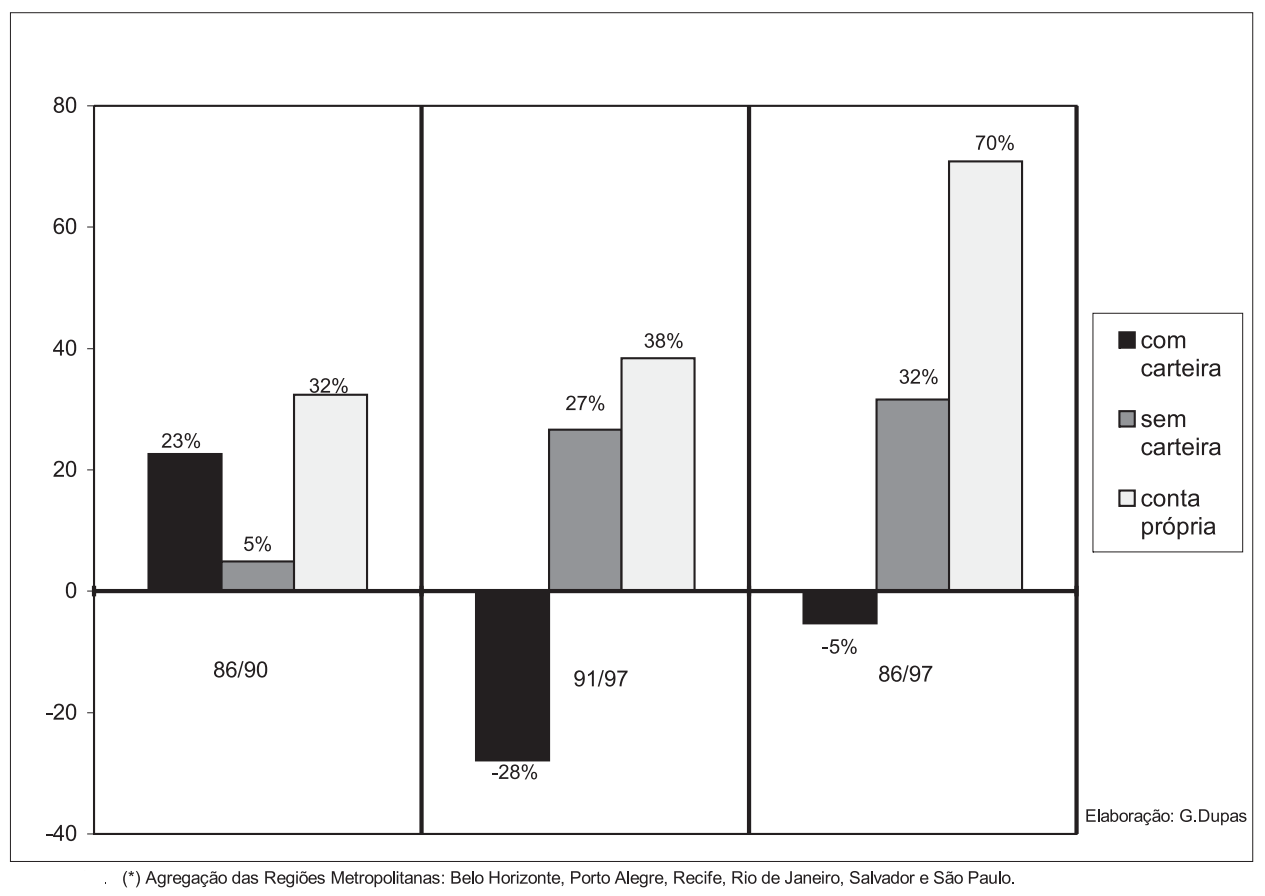

Gráfico 6: Porcentagem de empregos gerados (perdidos) por posição na ocupação - Brasil Metropolitano* - 1986-1997

Fonte: IBGE. 
Como conseqüência da forte tendência de flexibilização introduzida na economia brasileira pela abertura econômica acelerada, o mercado de trabalho transformou-se profundamente com conseqüentes alterações de natureza psicossocial, alteração ilustrada pelo gráfico 7. Pode ser observado que após vários anos em patamar razoavelmente estável, a partir dos 1990 as curvas relativas aos setores formal e informal se invertem rapidamente. Após pequena alteração logo após o Plano Real, a tendência é retomada nos anos mais recentes, com o setor informal tendendo a representar mais de $55 \%$ da mão-de-obra metropolitana brasileira.

Em apenas uma década é alterada a referência do mercado de trabalho, que deixa de ser o formal, com carteira assinada e direitos adquiridos. A possibilidade de obter uma ocupação passa a ser maior no setor informal, mas a referência social continua a ser, no inconsciente coletivo, estar empregado no setor formal.

\section{Quadro 2}

Número de empregos gerados (perdidos) segundo posição na ocupação no trabalho principal nas regiões metropolitanas* brasileiras

\begin{tabular}{|c|c|c|c|c|c|c|c|}
\hline \multicolumn{2}{|c|}{ Setor de Ocupação } & \multicolumn{6}{|c|}{ Empregos } \\
\hline \multicolumn{2}{|c|}{ Pop. Ocupada } & \multicolumn{2}{|c|}{ Período 86/90 } & \multicolumn{2}{|c|}{ Período 91/97 } & \multicolumn{2}{|c|}{ Período 86/97 } \\
\hline & $1985(1)$ & Acum.(2) & M.Anual & Acum.(3) & M.Anual & Acum.(4) & M.Anual \\
\hline Formal & 7.840 & 1.773 & 355 & -2.187 & -312 & -415 & -35 \\
\hline Informal & 6.188 & 1.067 & 213 & 1.666 & 238 & 2.732 & 228 \\
\hline Sem carteira & 3.073 & 151 & 30 & 820 & 117 & 970 & 81 \\
\hline Conta própria & 2.354 & 762 & 152 & 905 & 129 & 1.667 & 139 \\
\hline Empregador & 589 & 166 & 33 & -62 & -9 & 103 & 9 \\
\hline Outros & 171 & -11 & -2 & 4 & 1 & -8 & -1 \\
\hline Total & 14.028 & 2.840 & 568 & -522 & -522 & 2.318 & 193 \\
\hline
\end{tabular}

Fonte: IBGE.

Não podemos deixar de mencionar a atual polêmica sobre a medição do desemprego metropolitano e o conflito que se estabeleceu entre a metodologia do IBGE e a do Seade - o último mede o desemprego na região metropolitana de São Paulo. 


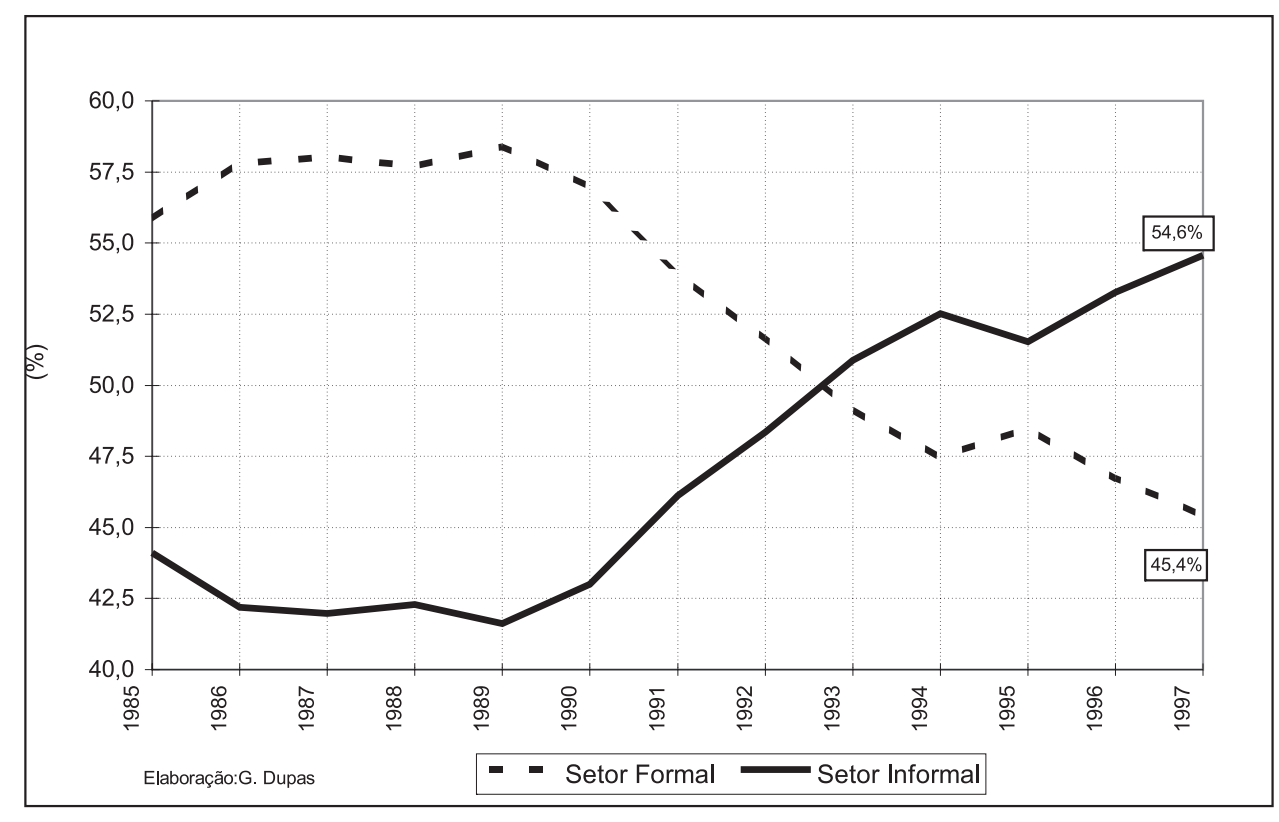

(*) Agregação das seguintes Regiōes Metropolitanas: Belo Horizonte, Porto Alegre, Recife, Salvador, Rio de Janeiro e São Paulo.

Gráfico 7: Distribuição relativa dos ocupados segundo posição na ocupação no trabalho principal, Brasil metropolitano - 1985/1997.

Fonte: IBGE.

No gráfico 8 apresenta-se as curvas de desemprego verificadas pelos dois institutos. A primeira evidência é a enorme diferença no nível do desemprego: o IBGE partiu de um valor em torno de $4 \%$ entre 1987 e 1988, enquanto o Seade já registrava para o mesmo período aproximadamente 10\%. Atualmente, no pico de desemprego de junho 1998, os valores são, respectivamente, 9,4\% e 19\%, significando um acréscimo de várias centenas de milhares de pessoas desempregadas só na Grande São Paulo, a valer o número do Seade. Outro aspecto observado diz respeito à aceleração das retas de ajuste, maior na curva proposta pelo Seade, a mostrar um agravamento mais radical da condição do emprego. No gráfico 9 e em suas legendas são explicadas as diferenças de critérios que conduzem a resultados tão diversos. O IBGE, escudado em metodologia internacional - que, diga-se de passagem, permite variações - considera qualquer trabalhador precário como empregado, enquanto o Seade registra parte desses postos como "desemprego oculto por trabalho precário". Além disso, para o último os "desalentados" - que desistiram de procurar emprego nos últimos 30 dias são registrados como desempregados. 


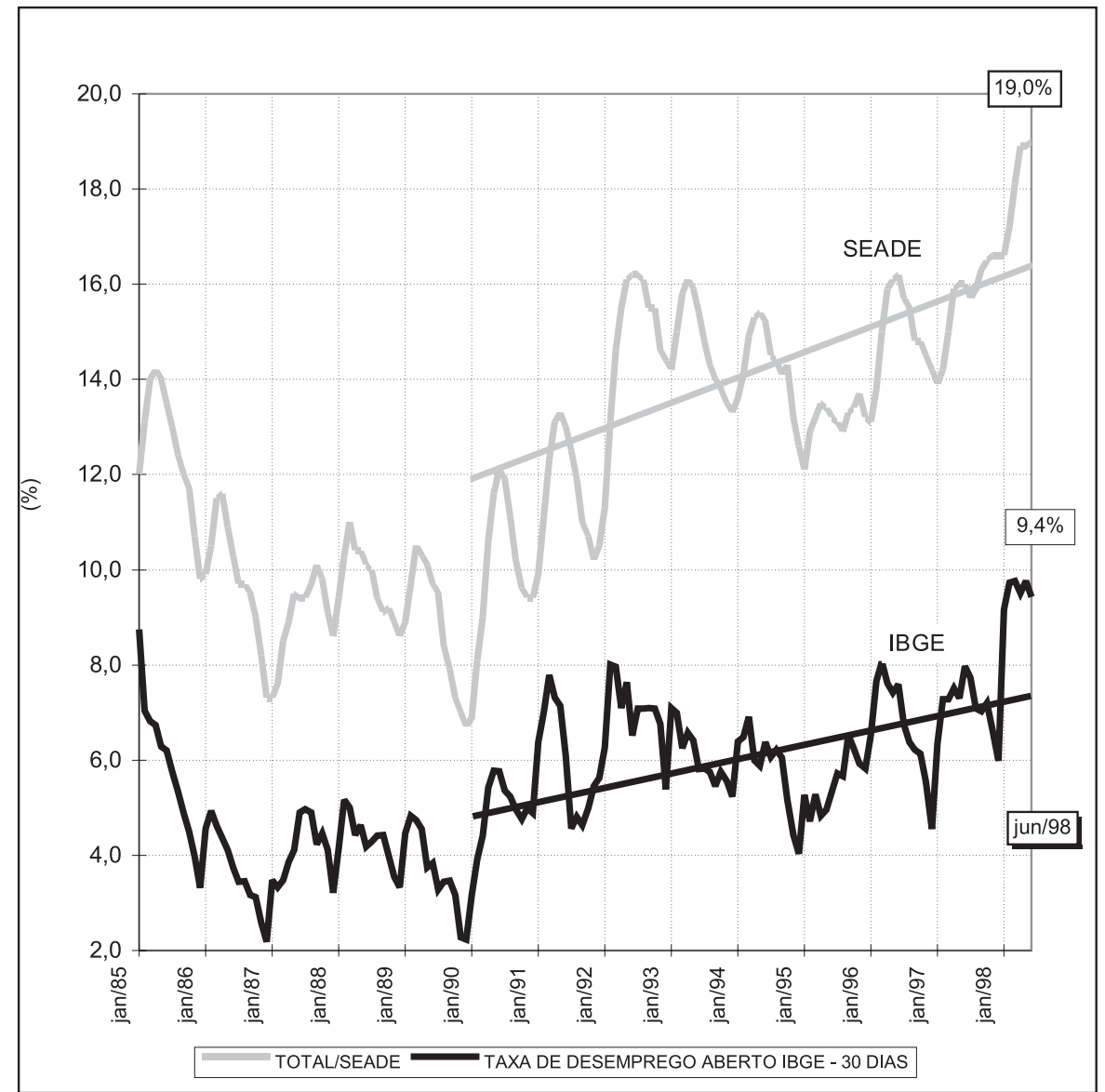

Gráfico 8: Taxas de desemprego - Região Metropolitana de São Paulo Fonte: PDE/Seade. Elaboração: G. Dupas.

Desemprego total Seade: soma entre desemprego aberto e desemprego oculto.

Qual o índice mais fidedigno para captar a atual realidade brasileira? Num país com as atuais características do mercado de trabalho brasileiro, deve-se considerar os dois porque se a precariedade - que vem junto com a informalização - aumenta, é preciso captá-la com maior sensibilidade. Não parece razoável usar a mesma metodologia para países com $5 \%$ ou $55 \%$ dos trabalhadores concentrados no setor informal.

Devemos levar em consideração um fator que permite atenuar, em parte, os índices de empregos no Brasil. Trata-se da forte incorporação de mulheres ao mercado de trabalho a partir de 1990 o que, juntamente com o eventual aumento do número de jovens que se dispuseram a trabalhar, 
fez o crescimento da PEA ser superior ao da população, conforme pode ser observado no gráfico 9, um fenômeno mundial que soma razões de natureza econômica (obtenção de renda mínima familiar) e outras de natureza psicossocial (mudança de status da mulher na sociedade). No Brasil ele significa um crescimento da PEA feminina - com relação à masculina - de 32,5\% no período 1985-1996.

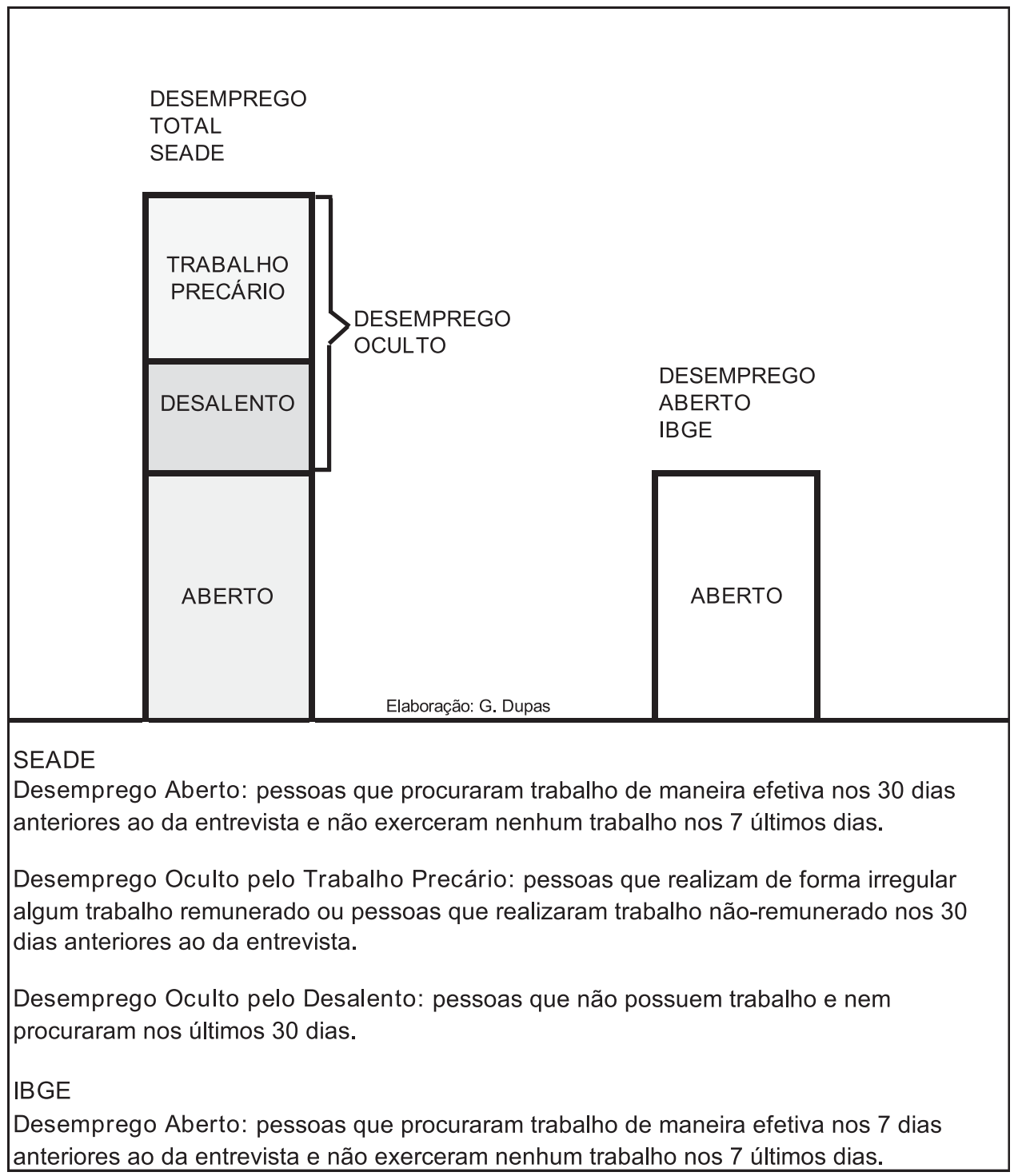

Gráfico 9: Critérios para o índice de desemprego - SEADE versus IBGE 
A questão da informalização do trabalho, também tendência mundial, adquire contornos mais dramáticos nos países periféricos. Para a melhor compreensão desse efeito é útil a observação dos dados pesquisados pelo Instituto Nacional de Estadísticas y Censos (Indec) sobre a Argentina. Utilizando metodologia internacionalmente difundida, essa instituição considera desempregada a pessoa que na semana de referência trabalhou menos de uma hora e procurou ativamente emprego (gráfico 10). Dado que várias pessoas precariamente ocupadas consideram-se mal ou subocupadas, o Indec complementa a pesquisa com o levantamento do número de subocupados na sua própria avaliação (correspondente a ocupados demandantes de emprego, no mesmo gráfico). Para a grande Buenos Aires, que concentra cerca de $40 \%$ da população do país, este número chega a quase $25 \%$ da PEA. Assim, embora o desemprego total pelo critério da curva A atinja 14,9\% para o total da população de cidades acima de 100 mil habitantes, a soma das duas curvas para a grande Buenos Aires atinge 37,7\%, incluindo desempregados ou ocupados demandantes de emprego. Vê-se, portanto, que a situação de desemprego e precariedade, profundamente agravados a partir de 1992, é mais grave na Argentina do que no Brasil.

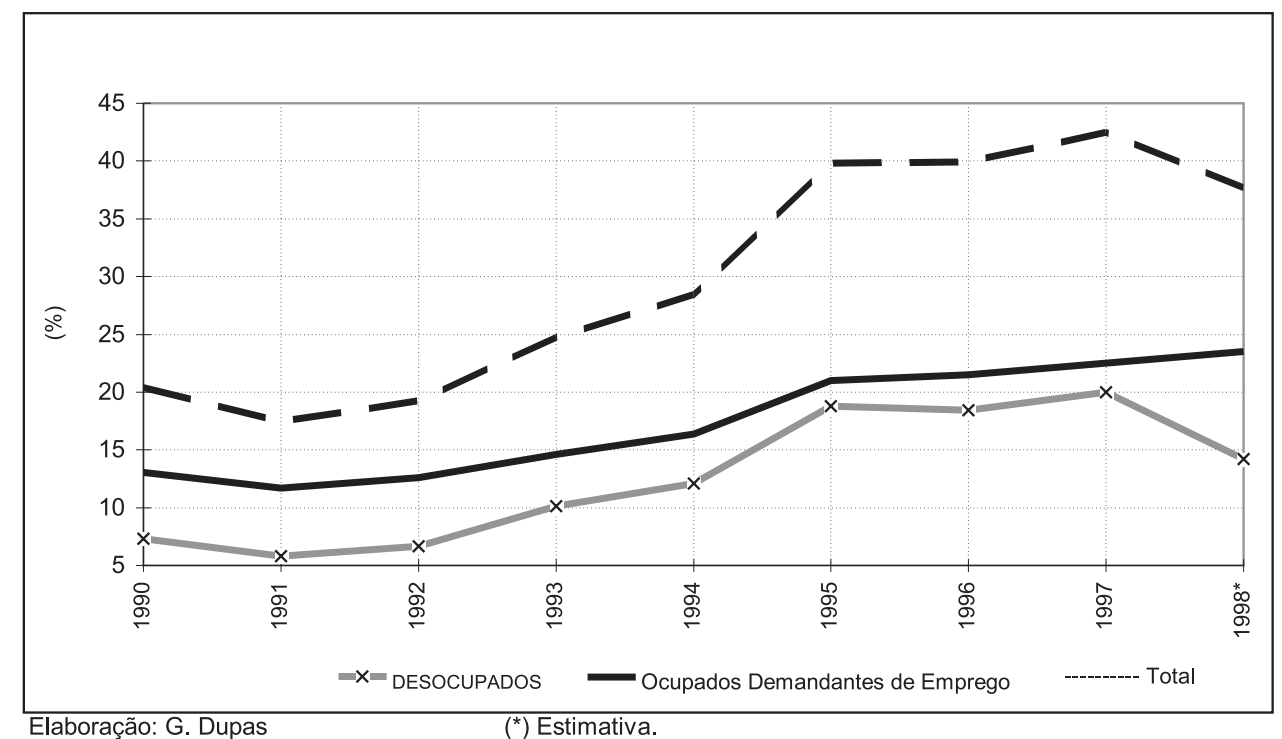

Gráfico 10: Taxa de desemprego e de ocupados demandantes de emprego na grande Buenos Aires, 1990/1998

Fonte: Indec. 


\section{A mudança de paradigma, a qualidade do trabalho e a pobreza}

Além da questão do desemprego é preciso analisar de que forma essa mudança de paradigma - que levou ao brutal crescimento do setor informal - afetou a qualidade do trabalho, ou seja, o nível e a estabilidade de suas rendas e os esquemas de proteção social.

O exame do gráfico 11 revela algumas surpresas. Tentativas de estabilização desse conturbado período da nossa história econômica tiveram, num primeiro momento, efeito positivo sobre as rendas reais médias dos indivíduos, especialmente o Plano Cruzado em 1986 e o Plano Collor em 1990. O último foi seguido por grande queda das rendas em função da pior recessão da década (1992), somada a forte arrocho salarial. A partir desse fundo do poço, houve contínua recuperação seguida ao paulatino crescimento do PIB, que se manteve em ascensão após o Plano Real, gerando boas notícias:

- a renda média do setor informal, especialmente na categoria Conta Própria, sempre liderou os saltos de renda;

- até o Plano Real, os ganhos de renda eram rapidamente perdidos; a partir de 1994, mantiveram-se e cresceram, alterando o perfil da massa salarial a favor do setor informal.

Por que, sendo essa a realidade, nas pesquisas de opinião, a sociedade revela uma forte sensação de insegurança quanto ao futuro de seu emprego e uma percepção de exclusão social crescente? Vamos às más notícias:

- a análise do gráfico 12, que apresenta o rendimento real médio por posição na ocupação, revela informações muito importantes. Observa-se durante todo o período analisado (1985-1996), que o rendimento real médio dos trabalhadores sem carteira manteve-se significativamente inferior (aproximadamente $30 \%$ a $40 \%$ ) ao rendimento dos trabalhadores com carteira (incluídos na remuneração os ganhos proporcionais de férias e $13^{\circ}$ salários). Embora essa diferença tenha se estreitado um pouco em função da maior recuperação de renda após o Real já relatada, ainda se mantém significativa. O mesmo acontece com relação aos trabalhadores por conta própria, sempre com renda inferior àqueles com carteira, apesar de seus ganhos relativos após o Real terem sido bem maiores, diminuindo em cerca de metade essa diferença quando comparados aos trabalhadores em carteira. No entanto, quando consideradas as médias - quando os trabalhado- 
res perderam suas funções no mercado formal e mergulharam no informal - sua renda sofreu uma queda expressiva, somada a uma nova e forte insegurança com relação ao seu futuro e à sua proteção social;

- apesar do crescimento relativo de renda dos setores informais, para usar um conceito piagetiano, há uma espécie de dor de passagem da heteronomia para a autonomia. Além do que, férias, feriados e fins de semana do trabalhador informal têm sabor de renúncia de renda, não de direito adquirido.

- devido ao trabalhador informal em vários casos "inventar" seu trabalho (vendedor de bolinhos, guardador de carros etc.), corre-se o risco de ver uma reformulação e radicalização da aplicação da antiga ética protestante do trabalho como novo conceito moral, o "vá trabalhar, vagabundo!" agora aplicado não às oportunidades de emprego disponíveis, mas ao "vá vender bolinhos, ora bolas!", o que poderá estabelecer uma nova e perigosa cisão social com a total ausência de responsabilidade social das elites em garantir crescimento econômico e oferta real de postos de trabalho;

- a partir de janeiro de 1998 estão surgindo indícios de reversão do crescimento e de queda de renda, aparentemente maiores que os sazonais, talvez influenciados pela crise internacional. É possível que se trate de um primeiro sintoma de esgotamento dos benefícios do Plano Real;

- o setor informal padece de uma relação mal resolvida com o Estado, na qual, ao mesmo tempo em que as autoridades vêem no setor informal uma "solução", tratam-no muitas vezes como marginal, dado nosso sistema tributário encará-lo como agente de evasão fiscal.

Para completar o quadro vamos analisar o que aconteceu com o segmento inferior de renda no Brasil nessas duas últimas décadas, antes de tudo, definindo quem são os pobres (Rocha, 1997). Trata-se de pessoas - tendo como referência unidades familiares - que não atendem à renda mínima necessária para a aquisição da cesta básica alimentar (padrão FAO), mais o custeio das necessidades mínimas de moradia, transporte e vestuário. A pesquisa que utilizamos define essa renda per capita como sendo de US\$ 110 para as regiões metropolitanas de São Paulo e Rio, US\$ 74 para o interior urbano de São Paulo e US\$ 37 para o Nordeste rural.

Uma inferência possível a partir dos dados apresentados no gráfico 13 (Sonia Rocha, 1997) é que a proporção dos pobres com relação à população total, que havia caído apenas 5 pontos percentuais de 1981 a 1993, 
diminuiu mais de 9 pontos após o Plano Real, considerado excelente avanço. Recentemente, porém, parece ter havido ligeira queda (0,7\%) de 1996 para 1997.

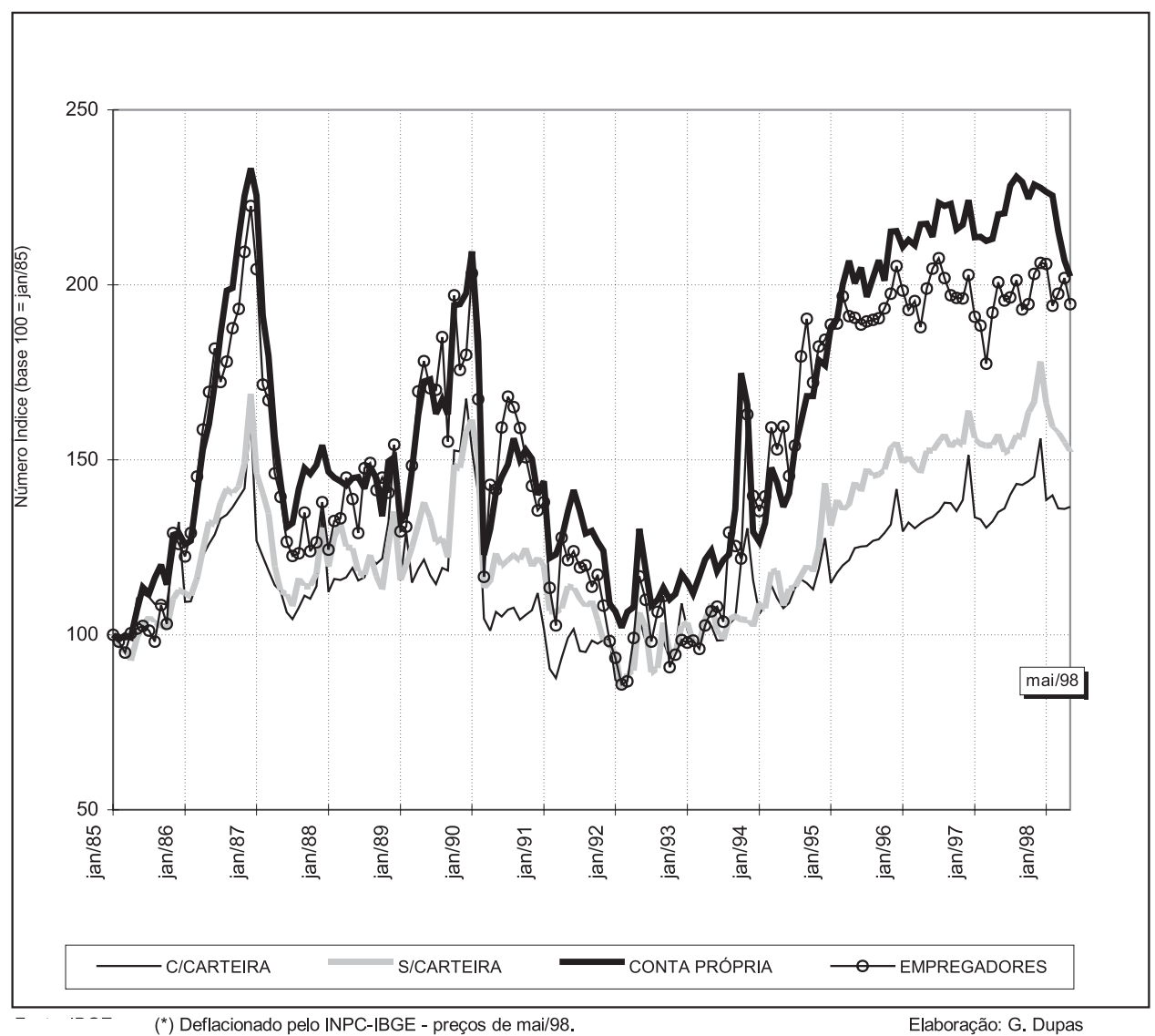

Gráfico 11: Brasil Regiões Metropolitanas - rendimento médio real* Posição na ocupação

Fonte: IBGE.

O que está acontecendo com a distribuição de renda dos 20\% mais pobres? A análise dos dados apresentados no gráfico 14 (Sonia Rocha, 1996) nos revela que com o Plano Real um número muito importante de brasileiros com rendimento próximo à linha de pobreza pôde sair da condição formal de pobres, um enorme avanço. Entretanto, a situação dos que continuaram pobres aparentemente se agravou. Houve maior distanciamento da média dos remanescentes da linha de pobreza, ou seja, a distribuição de renda entre os pobres parece ter piorado, acentuando o que se poderia chamar de lumpenização da pobreza. 


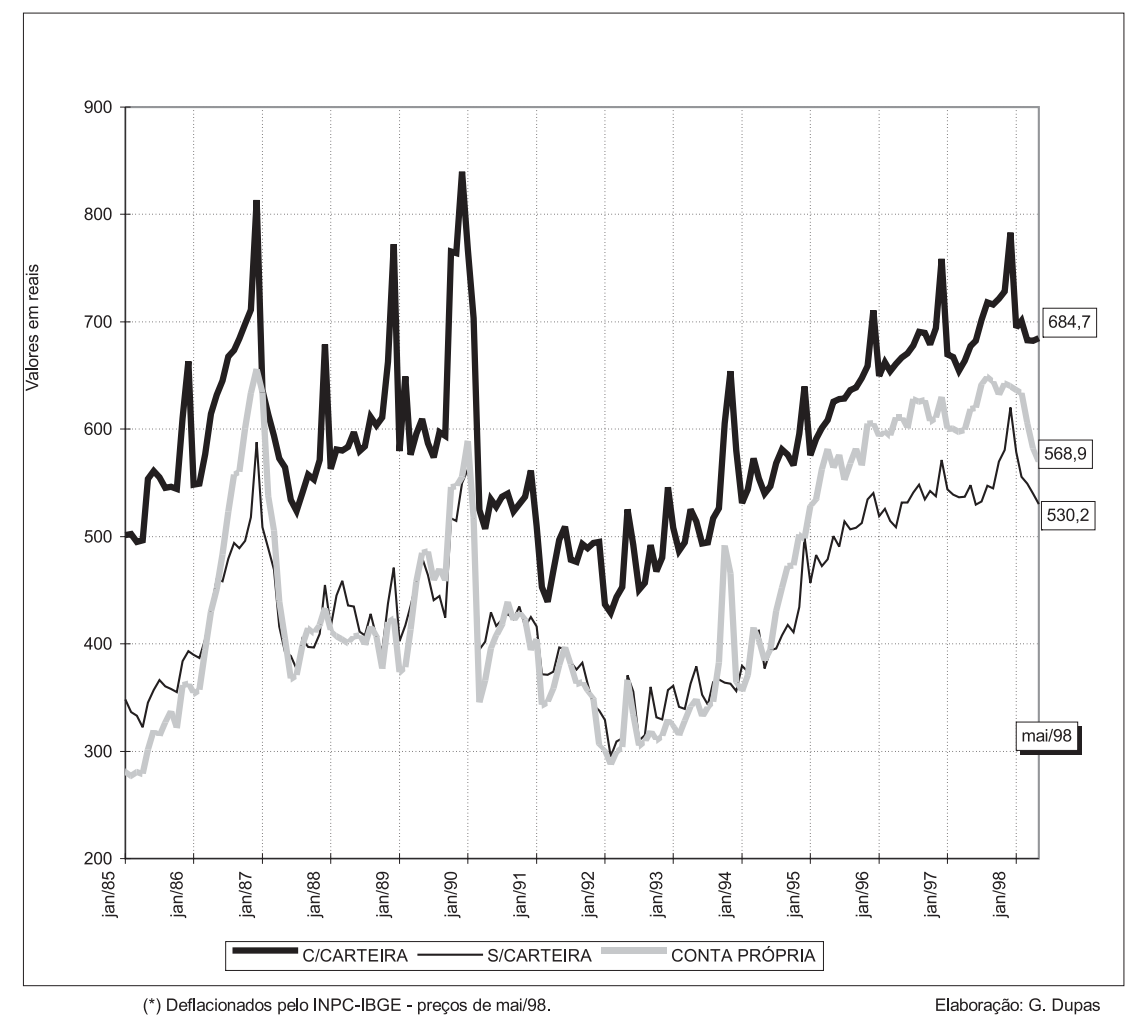

Gráfico 12: Brasil Regiões Metropolitanas - Rendimento Real Médio* Posição na ocupação

Fonte: IBGE.

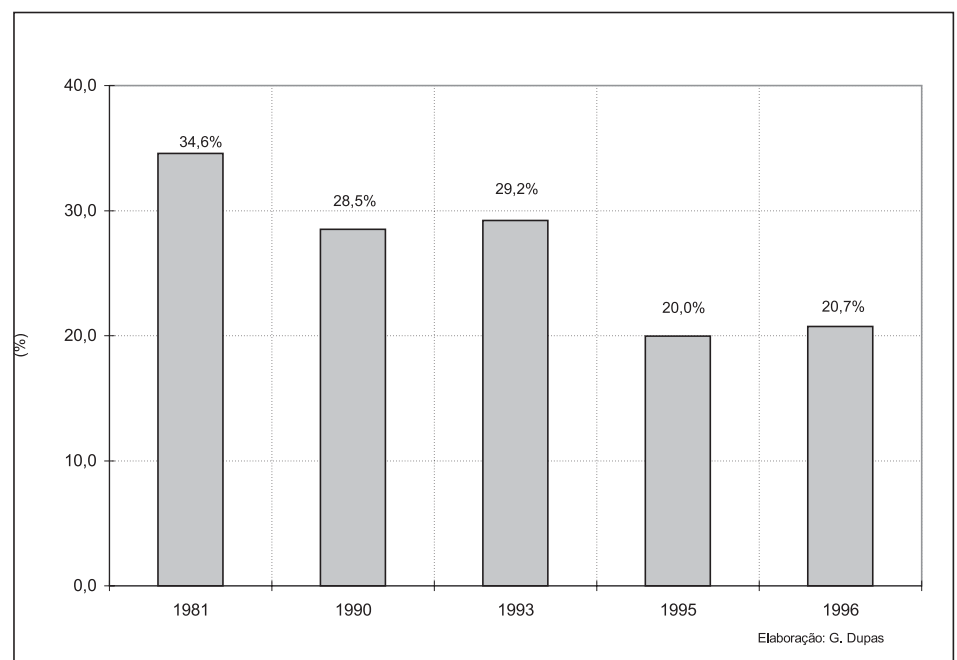

Gráfico 13: Proporção de pobres em relação à população total Brasil 1981/1996.

Fonte: PNAD/IBGE-IPEA. 


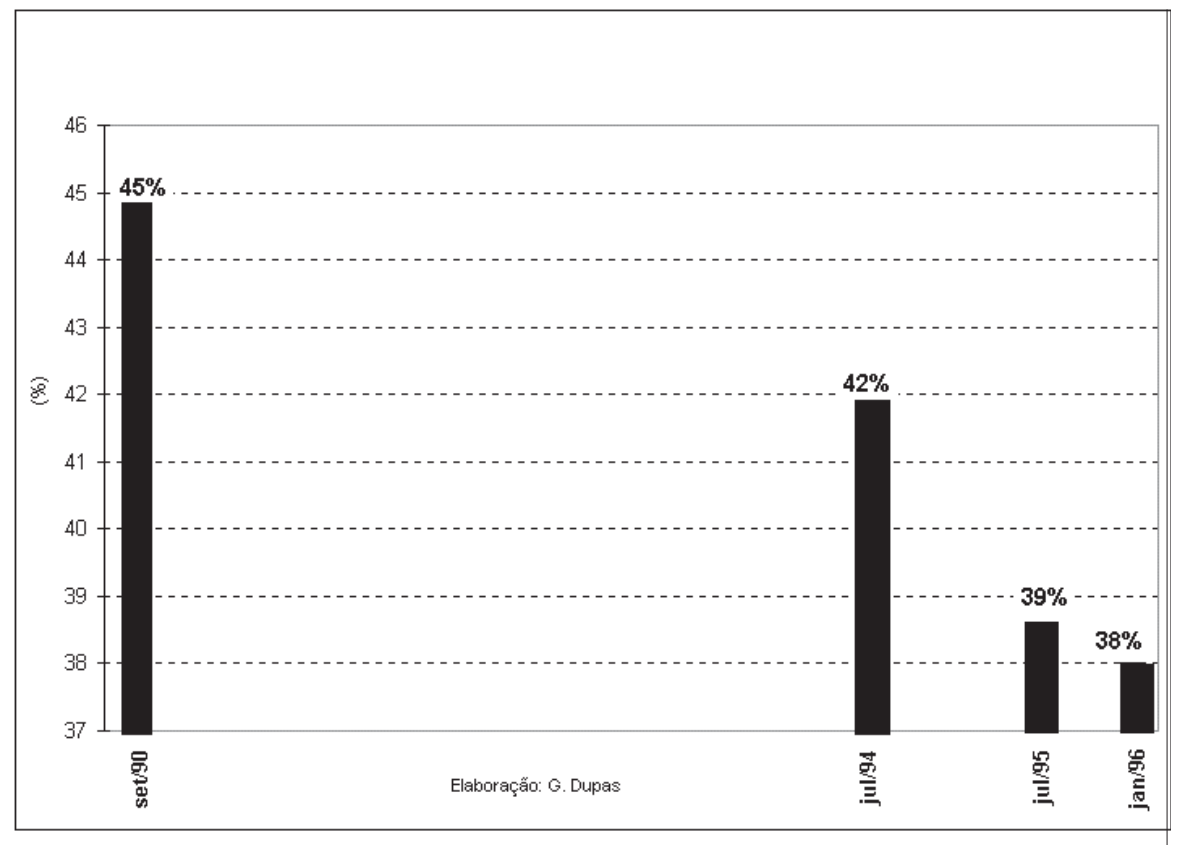

Gráfico 14: Renda média dos pobres como percentual do valor da linha de pobreza - Brasil Metropolitano 1990/96

Fonte: IBGE-IPEA.

\section{O futuro do emprego: do cinza ao negro}

A situação atual do emprego e da exclusão, sombra escura que paira sobre esta virada de século, teve algumas de suas características analisadas.

O que acontecerá com o futuro do emprego? Os especialistas internacionais mais renomados concordam que as tendências atuais predominantes são flexibilização do emprego e aumento das desigualdades. No entanto, suas opiniões sobre o futuro, variam do mais duro pessimismo ao otimismo moderado.

Começaremos citando uma opinião institucional, a da Organização Internacional do Trabalho. Segundo a OIT (1997-98) a mobilidade do capital desestabiliza a estrutura de salários dos sistemas nacionais. À debilidade dos Estados nacionais e dos sindicatos frente ao capital soma-se o crescimento do setor informal - precário quase por definição -, da economia, o que debilita ainda mais os trabalhadores. Na América Latina o trabalho informal cresceu quase 5\% ao ano entre 1990 a 1994, enquanto o formal a apenas $1 \%$ ao ano. Para a OIT o Estado tem o papel central de 
manter e restaurar a coesão social seriamente debilitada pelo crescimento da exclusão. É imperioso defender os empregos e garantir uma renda mínima para os que não conseguem sobreviver com seus ganhos.

Vamos agora a dois enfoques pessimistas: os de Reich (1993) e Rifkin (1995). Reich classifica a atual estrutura do trabalho em três categorias: serviços rotineiros de produção (tarefas simples e repetitivas que ainda exigem a participação humana em maior escala); serviços prestados "em pessoa" (garçonetes, enfermeiras, vendedores em geral) e serviços simbólicoanalíticos exercidos por especialistas em imagens abstratas (pesquisadores, engenheiros, executivos etc.)

Para o autor, os serviços rotineiros de produção e simbólico-analíticos podem ser prestados globalmente, competindo assim com os estrangeiros. Essa nova estrutura dos trabalhos está gerando uma situação inédita nos EUA: a pauperização das frações trabalhadoras menos qualificadas. De 1977 a 1990, a renda média dos 20\% mais pobres da população diminuiu $5 \%$, enquanto a dos $20 \%$ mais ricos foi incrementada em $9 \%$. A quantidade de trabalhadores pobres aumentou 23\% entre 1978 e 1987, ao mesmo tempo em que os altos executivos, no mesmo período, elevaram sua remuneração. Em 1960 um diretor executivo ganhava 12 vezes mais que um operário, deduzidos os impostos; em 1988 essa diferença passou a ser de 70 vezes mais.

Rifkin, por sua vez, considera que a articulação da automação e a reengenharia provocam o fim do emprego e que socialmente a tecnologia traz maiores desvantagens do que vantagens pois seu impacto no tecido social expulsa setores do sistema diferentes daqueles que estão sendo incorporados pelo novo modelo. Haveria declínio da força de trabalho global, polarização social crescente (os blue collar estão perdendo poder de compra), declínio da classe média norte-americana, profunda desintegração social e violência social crescente, considerando-se que $18 \%$ da população norte-americana vive em situação precária. Ainda segundo Rifkin, na OCDE 35 milhões de pessoas estão desempregadas e outras 15 milhões vivem de subemprego sendo a maior parte dos desempregados jovens. As poucas alternativas disponíveis seriam a reengenharia da semana de trabalho, o fortalecimento do terceiro setor e a globalização da economia social por meio das ONGs.

Finalmente, ainda que matizada por algumas contradições, uma visão otimista: para Castells (1998), a nova economia informacional não tem como conseqüência o aumento do desemprego. Os postos de trabalho industriais mais tradicionais terão o mesmo destino dos agrícolas; por ou- 
tro lado, estarão sendo criados trabalhos novos na indústria de alta tecnologia e no setor de serviços. $\mathrm{O}$ autor acredita que o desemprego é um problema europeu (conceito que, no mínimo, parece uma brincadeira de mau gosto considerando-se o grave desemprego dos países em desenvolvimento) fruto de políticas econômicas desacertadas e de um entorno institucional que desalenta a criação privada de emprego. Níveis tecnológicos mais elevados estariam relacionados a taxas de desemprego menores. No entanto, Castells concorda que o endurecimento da lógica capitalista desde a década de 1980 tem fomentado a polarização social apesar da melhoria ocupacional e que a flexibilidade dos mercados e dos processos cria as bases para um novo tipo de trabalhador: o trabalhador flexível.

Afirma ainda, contradizendo as profecias apocalípticas das análises simplistas, que há mais postos de trabalho e maior proporção de pessoas em idade de trabalhar empregadas que em nenhum outro momento da história, especialmente pela incorporação maciça da mulher ao trabalho remunerado, a qual não causou fraturas importantes no mercado de trabalho. Castells afirma que a difusão das tecnologias de informação não tem resultado em desemprego massivo, nem parece que resultará em um futuro previsível.

Apesar da visão otimista de Castells, nossa pesquisa parece evidenciar haver boas razões para preocupações quanto ao futuro do emprego no mundo, em especial nos países periféricos. O contínuo avanço tecnológico, hoje definido basicamente pelo setor privado, não parece garantir que as sociedades futuras possam gerar - unicamente por mecanismos de mercado - postos de trabalhos, ainda que flexíveis, compatíveis em qualidade e renda com as necessidades mínimas dos cidadãos.

A lógica da globalização e do fracionamento das cadeias produtivas, muito oportuna para a vitalidade do capitalismo contemporâneo, incorporou os bolsões mundiais de trabalho barato sem necessariamente elevarlhes a renda. Os postos formais crescem menos rapidamente que os investimentos diretos. E se no setor informal surgem oportunidades bem remuneradas no trabalho flexível, há também o acumulo do trabalho muito precário e da miséria. Nos países mais pobres principalmente, os governos atuais - comprometidos com a estabilidade - não têm orçamento suficiente nem estruturas eficazes para garantir a sobrevivência dos novos excluídos.

O paradigma do emprego está mudando e, apesar de haver algumas boas notícias, as razões para preocupação são inúmeras. 
Notas

1 Glosário de termos em inglês:

Blue-collars workers: os trabalhadores que realizam atividades produtivas (operários)

Buyer-driven: redes de empresas que são conduzidas pela principal empresa compradora

Clusters: nichos de localização espacial especializados.

Designers: projetistas

Global Supliers: fornecedores globais

Green-field investiments: investimentos em plantas produtivas totalmente novas.

Income gap ratio: Taxa que indica a distancia de uma variável a uma medida padrão.

Lean-pruduction: produção enxuta

Low-wage labor: mão-de-obra com baixos salários

Management: gerenciamento

Networks: redes de empresas.

Out-sourcing: diferentes formas de terceirização e subcontratação.

Part-time: trabalho realizado em tempo parcial.

Producer-driven: redes de empresas cuja estratégia é traçada pela empresa que conduz ou determina o processo produtivo.

Royalties and fees: pagamento de direitos relacionados a uma licencia ou uso de marca.

Skill-less: sem (ou com poucas) habilidades.

Trading networks: redes de empresas orientadas ao comércio exterior

Welfare State: o Estado que aplicou políticas keynesianas de geração ou estímulo da demanda, como modo dominante de intermediação entre os conflitos entre as classes sociais.

Welfare transfer: transferências de benefícios do Estado para os assalariados.

2 Coeficiente Gini: Índice de concentração de renda.

3 Índice que indica o coeficiente de correlação entre duas ou mais variáveis 
Referências bibliográficas

ARRIGHI, Giovanni. O longo século XX. São Paulo, Unesp, 1984.

BANCO MUNDIAL. The State in a changing world. Washington, World Development Report, 1997.

CASTELLS, Manuel. La era de la información. Madrid, Alianza Editorial, 1998.

DESAI, Meghnad. Drawing the line: on defining the poverty thereshold. In: Poverty, famine and economics development. The selective essays of Meghnad Desai, v. 2. EUA, Ed. Eduard Elgar Co., 1995.

DICKEN, Peter. Global Shift. London, Paul Chapman Publishing Ltd., 1992.

DRUCKER, Peter. The new realities. 1982.

Foreign affairs. Gazeta Mercantil, n. 12, set. 1997.

DUMOND, Jean-Pierre. Les systèmes de protection sociale en Europe, 1995.

DUNNING, John H. Multinational enterprices and the global economy, 1993.

DUPAS, Gilberto. Estratégias das transnacionais: oportunidades e riscos. São Paulo, IEA-USP, Coleção Documentos n. 44, abr. 1993.

Alca e os interesses do Mercosul. Col. Memo, FMAL, 1997.

Crise econômica e transição democrática. Editora Klaxon, 1986.

Competitive integration and recoverty of growth: risks and prospects. Brazil and the challenge of economic reform. The Woodrow Wilson Center Press, 1993.

A lógica econômica global e a revisão do Welfare State: a urgência de um novo pacto social. São Paulo, IEA-USP, Estudos Avançados n. 33, maio/ago. 1998.

EWALD, François. L’Etat providence. Paris, Grasset, 1986.

GEREFFI, Gary. New regional divisions of labor in a era of globalization. Texto apresentado na conferência GLOBALIZATION, THE FORMATION OF ECONOMIC BLOCS, NATIONAL STATES AND REGIONAL RESPONSE, Utrecht, The Netherlands, jun. 1997.

GLICKMAN, N.J. \& WOODWARD, D.P. The new competitors: how foreing investors are changing the US economy. 1989.

HOLCMAN, Robert. Le chômage. Paris, La documentation Française, 1997.

ORGANIZAÇÃO INTERNACIONAL DO TRABALHO. Industrial Relations, democracy and social stability. Genebra, Word Labor Report, 1997-1998. 
PAUGAM, Serge. L'exclusion l'État des savoirs. Paris, Éditions La Découverte, 1996.

POMERANZ, Lenina \& NUNES FERREIRA, Adriana. Structural adjustment and unemployment. In: ULRICH, Peter (ed.). Problems of structural change in the 21st century. Frankfurt/Madrid/Vervuet, Iberoamericana, 1996.

PRZEWORSKY \& WALLERSTEIN, E. O capitalismo democrático na encruzilhada. São Paulo, Novos Estudos Cebrap n. 22, 1988.

REICH, Robert. El trabajo de las naciones. Buenos Aires, Vergara Editores, 1993.

RIFKIN, Jeremy. The end of work. New York, Putnam Books, 1995.

ROCHA, Sonia. Pobreza no Brasil: principais tendências da espacialização. Rio de Janeiro, Ipea/Dipes, 1997.

Do consumo observado à linha de pobreza. Revista Pesquisa de Planejamento Econômico, v. 27, n. 2, p. 313-352, ago. 1997.

Renda e pobreza: os impactos do Plano Real. Rio de Janeiro, Ipea, Texto para Discussão n. 439, dez. 1996.

ROGERS, Gerry. What is special about social exclusion approach? In: GARRY ROGERS, Charles Gore \& FIGUEIREIDO, José (orgs.). Social exclusion: rethoric, reality, responses. USA, International Institute for Labor Studies, 1995.

SEN, Amartya. Poverty and famines: an essay on entitlements and deprivation. Oxford-UK, University Press, 1984.

SILVER, Hilary. Reconceptualizing social deisadvantage: thre paradigms social exclusion. In: GARRY ROGERS, Charles Gore \& FIGUEIREIDO, José (orgs.). Social exclusion: rethoric, reality, responses. USA, International Institute for Labor Studies, 1995.

THE FUTURE of the State. The Economist, 20 Sep. 1997.

UNCTAD. World Investment Report., 1994.

Trade and Development Report, 1996.

WOLFE, Marshall. Globalization and social exclusion - some paradoxes. In: GARRY ROGERS, Charles Gore \& FIGUEIREIDO, José (orgs.). Social exclusion: rethoric, reality, responses. USA, International Institute for Labor Studies, 1995.

RESUMO - O CONTÍNUO AVANÇO tecnológico global não parece estar garantindo que as sociedades futuras possam gerar, unicamente por mecanismos de mercado, postos de trabalho - ainda que flexíveis - compatíveis em qualidade e renda com as necessidades básicas da população mundial. A lógica da globalização e do 
fracionamento das cadeias produtivas incorporou parte dos bolsões de mão-deobra barata mundiais sem necessariamente elevar-lhes a renda. Os postos de trabalho formal crescem menos que os investimentos diretos. Se, por um lado, surgem oportunidades bem remuneradas no trabalho flexível, por outro, o setor informal também abriga o emprego muito precário e a miséria. E, especialmente nos países da periferia, os governos - comprometidos com a estabilidade - não têm orçamento suficiente e estruturas eficazes para garantir a sobrevivência dos novos excluídos. O paradigma do emprego está em definitiva mudança, e há inúmeras razões para preocupação quanto ao futuro da exclusão social no novo século.

ABSTRACT - CONTINUOUS GLOBAL advances in technology have apparently failed to ensure to future societies the ability to create flexible jobs exclusively through the use of market mechanisms, commanding income levels and being of such character that are compatible with the basic needs of the world population. The logic behind globalization and the segmentation of productive chains have, in part, absorbed pockets of cheap labor throughout the world without necessarily providing their workers with higher income levels. Formal employment is growing at a lower rate than direct investments. If, on the one hand, there are emerging and well compensated opportunities in the flexible labor market, on the other, the informal sector also spans precarious, insecure jobs and poverty. In the peripheral countries, particularly, governments - which are commited to stability - simplely do not have the funding and sufficiently effective structures to ensure the survival of the newly excluded. The employment paradigm is undergoing a definite shift, and there are myriad reasons for concern about the future of social exclusion in the new millenium.

Gilberto Dupas é coordenador da Área de Assuntos Internacionais e membro do Conselho Deliberativo do Instituto de Estudos Avançados da USP. É professor da FDC junto ao European Institute of Business Administration - Insead (França) e à Northwestern University - Kellog (EUA). Publicou vários livros, entre os quais Crise econômica e transição democrática.

Este artigo é uma síntese da investigação conduzida pelo autor no Instituto de Estudos Avançados da USP - com apoio do Cebrap - entre junho/1997 e agosto/1998. O texto completo será editado em livro. Tiveram participação ativa no suporte desse trabalho, em várias de suas etapas, os pesquisadores Adriana Nunes Ferreira (mestre em Economia), Florencia Ferrer (doutoranda em Sociologia), Laura Valladão de Mattos (doutora em Economia), Denilson de Souza (sociólogo e historiador) e Adalton de Oliveira (economista), todos eles da Universidade de São Paulo.

Preparação de original e revisão de provas por Hermínia Antonia Guedes Bernardi. 